\title{
LA EXPEDICIÓN DE ANTONIO RAIMONDI A LA PROVINCIA DE TARAPACÁ Y LA CONSTRUCCIÓN ESTATAL DE UN TERRITORIO NACIONAL PERUANO: COMENTARIOS Y TRANSCRIPCIÓN DE SU CUADERNO DE CAMPO (1853-1854)
}

\author{
Luis Castro Castro ${ }^{1}$, Pablo Guerrero Oñate ${ }^{2}$ y Carolina Figueroa Cerna ${ }^{3}$
}

\begin{abstract}
Resumen
Se transcriben y comentan las notas de campo de Antonio Raimondi referidas a la expedición que realizó entre fines de 1853 e inicios de 1854 a la provincia de Tarapacá por mandato del presidente José Rufino Echenique, con el propósito de verificar el potencial económico del salitre como generador de renta. En los comentarios a este cuerpo documental, por una parte, se describe la percepción que tuvo este naturalista italiano sobre el paisaje natural y humano de la entonces región más meridional del Perú y, por otra, se sostiene analíticamente que esta exploración fue parte de los complejos y contradictorios procesos de conformación del territorio nacional adscrito al proyecto republicano encabezado por el aparato estatal controlado principalmente por la élite limeña.
\end{abstract}

Palabras claves: Raimondi - Tarapacá - territorio nacional - Perú.

Abstract

Antonio Raimondi's field notes about the expedition carried out between the late 1853 and the early 1854 to Tarapacá Province by order of the president José Rufino Echenique are transcribed and commented with the purpose of verifying the economic potential of saltpeter as a revenue generator. In the comments to this body of research it is described on one hand, the perception of this Italian naturalist about the natural and human landscape of the then southernmost region in Perú, and, on the other, it is analytically supported that this exploration was part of the complex and contradictory processes of the formation of the national territory assigned to the republican project led by the state apparatus that was mainly controlled by the elite of Lima.

Keywords: Raimondi - Tarapacá - national territory - Peru. Recibido: enero 2016. Aceptado: agosto 2016.

\section{* Introducción}

El naturalista italiano autodidacta Antonio Raimondi arribó al puerto del Callao el 28 de julio de 1850 (Cayo 1982: 10; Bonfiglio 2004: 254-256). En ese entonces transcurría el primer gobierno de Ramón Castilla (18451851) y el país vivía un paréntesis de relativa estabilidad tras un período extenso de convulsiones políticas, además de una prosperidad económica otorgada por la explotación del guano en las islas Chincha iniciada en 1840 (Basadre 2014; Contreras y Cueto 2000).

Arribando al Perú en un momento de inflexión, Raimondi se vio enfrentado al reto de aportar al conocimiento científico de este país como parte fundamental del proceso de consolidación del Estado-nación (Villacorta 2006: 25). Considerado como parte de la estirpe de los viajeros románticos (Núñez 1987), cuyo anhelo era "encontrar como Humboldt la armonía de los fenómenos de la naturaleza con los nuevos sentimientos y aspiraciones del hombre y el racionalismo renovador de los enciclopedistas" (Núñez 1987: 20), su motivación provino de la ilusión que despertó en su niñez la imagen exótica de la naturaleza y la geografía americana. De este modo, el Perú surgió como destino luego de haber revisado toda la información disponible sobre

1 Centro de Estudios Avanzados, Universidad de Playa Ancha, Traslaviña 450, Viña del Mar, CHILE. Email: luis.castro-cea@ upla.cl

2 Centro de Estudios Avanzados, Universidad de Playa Ancha, Traslaviña 450, Viña del Mar, CHILE. Email: p.andresguerrero@ live.cl

3 Instituto de Estudios Internacionales (INTE), Universidad Arturo Prat, Av. San Pablo 1796, Santiago, CHILE. Email: carocerna@yahoo.com 
los países de la América meridional al ofrecerle la mayor diversidad de paisajes naturales y ser menos conocido para la ciencia (Raimondi 1874: 7-9).

Será en este escenario, que convocaba un impulso modernizador no solo institucional y económico sino además cultural y científico, donde Raimondi encuentra lugar a sus inquietudes e intereses como naturalista. Acogido por el médico Cayetano Heredia, uno de los artífices de la ciencia peruana decimonónica, a los pocos días de su llegada al Perú éste le encarga la clasificación y organización de las colecciones del Museo de Historia Natural del Colegio de la Independencia que él dirigía, ${ }^{4}$ además de ofrecerle al año siguiente los cursos de Historia Natural (Botánica y Zoología) y Química que se impartían en este centro educativo (Bonfiglio 2004: 45-53; Villacorta 2003: 27).

Inquieto por sus afanes naturalistas, Raimondi comenzó en 1851, a la par del rol de docente en el Colegio de la Independencia, sus primeras y breves expediciones a los alrededores de Lima, llevando a cabo en el año de 1852 el primer recorrido de magnitud a la zona de Chanchamayo (Bonfigio 2004: 53; Villacorta 2003: 32), cumpliendo su anhelo de infancia de conocer la selva tropical (Raimondi 1874: 42).

Entre 1851 y 1858, etapa descrita como de "acumulación de experiencias sobre las características geográficas y sociales más relevantes del Perú" (Villacorta 2003: 31), Raimondi realizó nueve viajes cortos, seis de ellos financiados por él y tres (a las islas Chincha, a la provincia de Tarapacá y a Paita y Tumbes) que fueron acometidos por encargo del Estado peruano (Seiner 2003: 522). De este modo, dichas excursiones fueron excepcionales para este primer ciclo expedicionario. En efecto, recién a partir de 1859 comenzó a recibir apoyo regular de los gobiernos, inaugurando con ello lo que Giovanni Bonfiglio (2004: 67-167) denomina los "grandes viajes de exploración" y Luis Villacorta (2003: 31) los "viajes complementarios" de larga duración que "fueron organizados en sucesivos tramos que abarcaron ordenada y transversalmente el norte, el centro y sur de la República".

La rápida reputación que alcanzó en sus dos primeros años de residencia en el Perú, tanto a través de sus exploraciones

4 El Colegio de la Independencia fue la primera escuela formadora de médicos de Lima. En 1856 pasó a conformar la Facultad de Medicina de la Universidad Mayor de San Marcos. como en su calidad de docente del Colegio de la Independencia, le posibilitó a Raimondi ser convocado a mediados de 1853 por el gobierno de José Rufino Echenique (18511854) para que formara parte de la comisión científica destinada a verificar las reservas de guano de las islas Chincha así como, a fines del mismo año, a integrar la expedición encargada de evaluar la calidad y posibilidad de explotación económica del salitre y el bórax contenidos en los lejanos parajes tarapaqueños (Cayo 1982: 18; Guevara 1993: 132; Seiner 2003: 520).

En su recorrido por Tarapacá, Raimondi no solo buscó confirmar la existencia y ubicación de yacimientos de salitre y bórax, lo mandatado gubernamentalmente, sino además puso atención en los rasgos geológicos, la fauna, la flora, los asentamientos y las actividades económicas de las poblaciones locales, moldeando con ello su perfil expedicionario sustentado en una percepción de la naturaleza como una totalidad que obligaba a una comprensión de ella igualmente cabal (Seiner 2003: 528).

Considerando que la importancia de los datos geográficos, geológicos, zoológicos, botánicos, económicos y demográficos recopilados por Raimondi en Tarapacá tuvo que ver con dos dimensiones, la formación del territorio nacional y la articulación agencial del aparato estatal peruano, el propósito central de este comentario a sus notas de campo será describir cómo la visita a Tarapacá fue parte de un ejercicio impulsado desde un Estado que intentaba organizarse desplegando algunas acciones tales como financiar o promover exploraciones, mandatar la confección de mapas y cartillas topográficas, impulsar algunas comisiones auxiliares de ingenieros-geógrafos, entre otras. Es decir, iniciativas destinadas a la formación de un conocimiento territorial donde el rol de la ciencia fue precisamente objetivar la diversidad medioambiental y social al amparo de un ejercicio mensurador que buscaba homogenizar -a través de categorías que permitieran ordenar la visión sobre el espacio- a los individuos y las riquezas que allí se localizaban, dando como resultado la conformación de un paisaje en correspondencia con recursos naturales en explotación o potenciales de capitalizar.

\section{$\diamond$ El documento}

Las notas de campo sobre la expedición a la provincia de Tarapacá, realizada entre noviembre de 1853 y enero de 1854 , 
fueron ubicadas en el Archivo General de la Nación del Perú bajo el rótulo Colección Antonio Raimondi, Libreta $\mathrm{N}^{\circ}$ 2, Provincia de Tarapacá 1853 . Consta de 122 páginas, donde se despliega el itinerario seguido desde la partida en el Callao hasta el periplo por la quebrada de Tarapacá, además de contener numerosas observaciones y algunas ilustraciones (a mano alzada) del propio Raimondi. Su paso por el mineral de Huantajaya en compañía de William Bollaert al final de la expedición (Bermúdez 1963: 133, nota 1), lamentablemente no se encuentra en este cuaderno.

El contenido de esta libreta de campo tuvo una primera transcripción en el Tomo V de El Perú. Estudios Mineralógicos y Geológicos publicado póstumamente por la Sociedad Geográfica de Lima y el Cuerpo de Ingenieros de Minas en 1913. Sin embargo esta versión, por una parte, modificó de manera importante el estilo original, editando su contenido para lograr un texto narrativamente más fluido y, por otra, obvió parte del mismo (como las descripciones botánicas), las ilustraciones, las observaciones y la compaginación primitiva; y si bien tiene el mérito de ser la primera transcripción de estas notas, no es plenamente fiel al texto original.

En la presente versión, por una parte, hemos mantenido la estructura original para corresponder a los contenidos, su secuencia y énfasis; por otra, desplegamos las abreviaturas y ajustamos la grafía y puntuación para soslayar errores evidentes. También, para darle mayor valor a la transcripción, se ha agregado un índice onomástico y toponímico. En cuanto a la compaginación, es necesario aclarar que Raimondi la estableció a razón de planas abiertas, lo que mantenemos íntegramente. En la transcripción publicada en 1913 se omitieron tres comentarios al margen, los que han sido recuperados indicándolos con un asterisco tal cual como están en la bitácora. Al mismo tiempo incorporamos notas correlativas y numeradas a efecto de aclarar o ampliar alguna información, como igualmente para adjuntar anotaciones de Raimondi que están en su libreta de campo, pero fuera de la secuencia diacrónica del relato de la expedición, y que estimamos relevantes. Ellas son: nota 35, descripción del puerto de Islay (originalmente en las páginas 56 y 57 de la libreta); nota 36, listado de autoridades políticas (en la página 60); nota 39, referencia a los geoglifos de Pintados (en la página 61).

\section{* El itinerario de viaje}

El 3 de noviembre de 1853, a las cuatro de la tarde, Antonio Raimondi junto al ingeniero Luis Mariani partieron desde el Callao rumbo a la entonces lejana provincia de Tarapacá a bordo del vapor Bolivia. Al día siguiente, a las once de la mañana, arribaron al puerto de Pisco. Aquí la embarcación permaneció apenas una hora para tomar dirección al puerto de Islay, al que llegaron el 6 de noviembre a la una de la tarde para salir una hora después hacia Arica, donde anclaron el 7 a las once y media de la mañana (Raimondi 1853: 2-3). De Arica dirá que es una "pequeña ciudad" de aspecto "bastante agradable tanto mirada de la mar como en tierra" (Raimondi 1853: 3). En esta localidad se quedó once días, para zarpar el 17 a las cinco de la tarde en el vapor Apurímac con destino al puerto de Iquique donde recaló el 18 a las dos de la tarde (Raimondi 1853:4).

En Iquique permaneció seis días ajustando los preparativos para, finalmente, iniciar su marcha el 24 de noviembre con destino al pueblo pampino de la Noria Nueva. Fue así como, armonizando sus motivaciones personales con los intereses y deseos del Estado peruano, Raimondi da comienzo a una expedición que lo llevó por distintas localidades de la pampa salitrera de la provincia y lugares aledaños, desplazándose en función de la existencia de aguadas.5 Por no ser de interés del Estado peruano, mandatario y financista de esta exploración, no recorrió la zona altiplánica ni gran parte del área precordillerana, ${ }^{6}$

5 El considerar las aguadas para determinar las rutas a seguir se sustentó en que éstas, a razón tanto de los requerimientos de consumo humano como de los animales empleados en la extracción y carga minera, conformaban georreferencias que delineaban el espacio desértico pampino de Tarapacá, el área con menos recursos hídricos superficiales de toda la provincia. Consecuentemente, la gran mayoría de los caminos, vigentes o abandonados, estaban trazados en concordancia con las ubicaciones de estas aguadas a la vez que demarcaban la posición de los asentamientos estuvieran o no habitados.

6 Con la misión de verificar la reservas de salitre existente en la remota provincia de Tarapacá, Raimondi trazó en la ida un recorrido en dirección norte-sur que lo llevó preferentemente por la seccional poniente de la Pampa del Tamarugal (La Noria, Calate, Quillagua) y en la vuelta una ruta en dirección sur-norte hacia la capital San Lorenzo de Tarapacá por su costado oriental (Challacollo, Pica, Mamiña). De este modo, las zonas altiplánica y precordillerana no revistieron mayor importancia para esta expe- 
un antecedente no menor en cuanto a los rasgos de este viaje que abordaremos más adelante.

En el poblado pampino de la Noria Nueva y sus alrededores estuvo hasta el 5 de diciembre observando la explotación del salitre, además de conseguirse una carpa y abastecerse de víveres para un mes. El día 6 emprende un recorrido por la Pampa del Tamarugal partiendo por el abandonado pueblo de Rinconada que había servido para "beneficiar los metales de las célebres minas de Huantajaya y Santa Rosa" (Raimondi 1853: 12). De Rinconada le llamaron la atención las casas deshabitadas sin techo, los restos de una pequeña capilla y un pozo de agua que aún estaba activo y que se ubicaba en una especie de corral llamado Cosallón de la Rinconada pocas cuadras antes de llegar al mencionado caserío (Raimondi 1853: 12-13).

El 8 de diciembre, a las dos de la tarde, se dirigió a Challapozo, lugar al que llegó a las seis pasado meridiano del mismo día. Sobre esta localidad mencionó que "consiste en una sola casita habitada y en alguna otra destruida [que] al presente es la mansión de nuestro guía" (Raimondi 1853: 15). El día 9, de madrugada, salió por el camino de la Cabrería examinando el terreno para reconocer si tenía borato de cal. En este trayecto pasó por la aguada de Reyes distante una legua de Challapozo (Raimondi 1853: 15-16). El 11 partió con dirección al Tronco pasando por Challapocito. El Tronco lo describió como un "pequeño grupo de tamarugos" que a poca distancia tiene agua muy salobre que no se puede beber. A las cuatro de la tarde de este día 11 arribó a la aguada de Chanavaya, regresando a Challapozo para pernoctar (Raimondi 1853: 20).

El 12 de diciembre desde Challapozo partió con dirección a la aguada de Santa Ana para llegar al bosque de tamarugos llamado Monte Grande. En este trayecto visitó las aguadas de Lucas Palape, Hidalgo y de Don Francisco, pasando nuevamente por la Noria Nueva (Raimondi 1853: 20-21) para volver a Challapozo donde instaló el campamento hasta el 14 de diciembre, día que tomó dirección al Pozo de Quinto (Raimondi 1853: 23). El 15 se dedicó a recorrer los alrededores del pozo para levantar el campamento el 16 con rumbo al sur, puntualmente hacia las oficinas salitreras de Los Linches que habían sido

dición, siendo únicamente descritas en términos macro y superficiales. propiedad de Juan Williamson (Raimondi 1853: 25). En este sector se arrimó a la Aguada Nueva para, al día siguiente, dirigirse a la Aguada Vieja (Raimondi 1853: 26). El 18 emprendió viaje hacia el monte de La Soledad para inspeccionar sus alrededores, descansando en el Puquio de los Quillas. El 19 se trasladó hacia Calate, no sin antes recorrer el monte de La Soledad, transitar por el camino hacia Huatacondo y pasar por los Puquios de Huatacondo (Raimondi 1853: 27-29).

De Calate, ubicado a orillas del río Loa, dijo "no es un pueblo" sino "solamente una pascana por lo que van a Cobija u otras partes" (Raimondi 1853: 30). Habiendo pasado la noche en este lugar, el 20 en la mañana enfiló hacia Quillagua, la localidad más importante asentada a las orillas del río Loa en su parte intermedia y paso obligado para quienes se aventuraban en la pampa salitrera. En este lugar estuvo dos días, 21 y 22 de diciembre, con el objeto de hacer descansar a los animales y a la comitiva (Raimondi 1853: 31-35).

Repuestas las energías, reanudó su viaje a Tamentica el día 23 (Raimondi 1853: 35). En la primera jornada de este trayecto pasó por las pascanas de Tambillo y Sipuca, lugar donde durmió. El 24 salió de Sipuca, pasando previamente por las quebrada de Maní y Honda, hasta llegar a su destino. Desde Tamentica recorrió la Pampa de Chelis y el valle de Tiquina (Raimondi 1853: 36-38). El 25 se dirigió a Huatacondo y regresó a Tamentica para emprender viaje hacia Matilla el 26 de diciembre. En su recorrido hacia Matilla pasó por el Puquio de Obregón (Raimondi 1853:39-41).

En el oasis de Pica estuvo hasta el 29 de diciembre inspeccionando los pueblos de Matilla, Pica y el valle de Quisma, fecha en la cual partió rumbo al pueblo de La Tirana pasando preliminarmente por La Noria Antigua, localidad en la que estuvo hasta el 31 de ese mes (Raimondi 1853: 42-50). Describió Matilla como "un pueblo regular cuyas casas presentan una buena vista" (Raimondi 1853: 41). A Pica, en tanto, lo señaló como "otro pueblo más grande que Matilla" (Raimondi 1853: 44). De La Tirana, por su parte, dijo que era el pueblo mejor constituido de la pampa aledaña a Canchones (Raimondi 1853: 49).

El 1 de enero de 1854, entrando en la fase final de su recorrido, se dirigió rumbo a la quebrada de Tarapacá, vi- 
sitando en su trayecto el valle y la localidad de Mamiña que describió como una quebrada que tenía termas sulfurosas y aguas que no "llegan a la pampa", la quebrada de Quipisca que la caracterizó por poseer un "pequeño chorrito de agua que no basta para la cultivación y solamente se cultiva en tiempos de avenida", el pueblo de Guaraciña que le llamó la atención porque estaba habitado por personas que se dedicaban al "cultivo de un poco terreno teniendo muy poca agua" y, finalmente, San Lorenzo de Tarapacá que a pesar de su condición de capital de la provincia tenía "calles muy turtuosas" y casas construidas con un "poco de solidez" (Raimondi 1853: 50-52).

\section{* LA Noción DE TERRITORIO: UNA MiRada EN PERSPECTIVA}

El concepto territorio en las últimas tres décadas ha tenido un extenso y fructífero abordaje tanto teórico como metodológico, que ha puesto en tela de juicio la concepción naturalista instalada en el siglo XIX como resultado de los intereses asociados a la expansión de los Estados nacionales y el capitalismo (Benedetti 2011).

En perspectiva, se pueden reconocer dos nociones generales en las cuales se ha sostenido la idea de territorio. Por una parte, como espacio absoluto, aproximación donde el territorio se entiende como el soporte natural para la vida del hombre. Por otra, como espacio diferencial o intersticial, solventado en una postura analítica crítica que señala que el territorio es, ante todo, una construcción social (Sánchez 1991; Sack 1986; Santos 1994 y 1996). La primera, siendo parte de la tradición ilustrada, es decir, positivista y naturalista, se asentó en una orientación estadocéntrica al determinar de modo estricto y excluyente la relación Estado-territorio y el ejercicio ineludible de la soberanía estatal, campo del cual fueron partícipes precisamente los exploradores decimonónicos como Antonio Raimondi. La segunda, en tanto, situada en una perspectiva de cuestionamiento a los moldes de dominación capitalista, sitúa lo territorial en tres esferas principales: 1) el de las relaciones de poder a partir de la sanción que el Estado no es la única fuente que los genera; 2) el despliegue espacial de las empresas transnacionales; 3) y los procesos de apropiación y la transformación del medio natural, poniendo atención en cuestiones tales como las estrategias para controlar áreas necesarias para la vida social y la verificación de que la realidad espacial no solo está constituida por las estructuras sino también por las acciones de los sujetos, es decir, donde se desarrollan prácticas sociales no reductibles a los parámetros formales del espacio controlado por el Estado (RoulleauBerger 1999), consecuentemente cada grupo social produce su espacio social propio, no colonial, sincrónica y diacrónicamente (Hiernaux-Nicolas 2004: 18-19).

Territorio, entonces, deduce la conformación de territorialidad, es decir, la pertenencia a un lugar a partir de procesos colectivos de identificación y representación que permeabilizan (e incluso desconocen) las fronteras políticas y la apropiación estatal del espacio (Rodríguez 2010; Precedo 2004). Así, el territorio estatal es uno más entre los territorios posibles configurados a partir del engranaje de la especificidad geográfica con la sociocultural (Bozzano 2009). Con esto, adquiere relevancia el hecho de que el territorio no es únicamente un objeto dado donde los sujetos están supeditados a condiciones y fuerzas externas, tampoco un resultado de procesos estatales donde los sujetos están ausentes, sino también un constructo (objetivos políticos e históricos) por hacer (Dematteis y Governa 2005: 37-39).

Siendo el territorio pábulo de relaciones de poder y dominación a la vez que un ámbito fructífero de pluralidades agenciales de los sujetos en distintos niveles, escalas y contextos, la complejidad no solo tendrá que ver con la reproducción de homogeneidad por parte de los poderosos, sino igualmente con las resistencias de los grupos subalternos, lo que Michael Storper (1997) identificará como la desterritorialización y re-territorialización selectiva; es decir, aunque la acción globalizante (generalmente estatal) genere modelos que simplifiquen la diversidad, la movilidad de la información social y cultural sigue recorridos que a menudo se escapan a las lógicas impositivas. En efecto, algunas de ellas se desplazarán ampliamente más allá de las fronteras político-administrativas; otras en cambio serán parte, residual o protagónicamente, de los circuitos nacionales o regionales; y por útimo estarán las consideradas inmóviles por situarse estrechamente a cierta especificidad local, y no por ello serán menos importantes (Amin 2000).

Lo interesante a partir de lo anterior será que el nexo entre la organización territorial, la transformación de los 
lugares y los niveles de la acción política, provocará que parte de la configuración del territorio sea resultado, por un lado, de un debilitamiento de la centralidad y de la capacidad de gobierno del Estado-nación y, por otro, de la emergencia de las modalidades infra y supranacionales de organización territorial (Vanier 1999; Harvey 1989, Brenner 1999), proceso que precisamente se verificará para el caso de Tarapacá al ser parte durante el siglo XIX de dos territorios nacionales (peruano y chileno) como resultado de una guerra (la del Pacífico), también de un territorio macrorregional articulado desde mucho antes de la existencia de las repúblicas nacionales (el centrosur andino), de uno microrregional ligado a la industria salitrera (el Norte Grande) y, por último, de uno estrictamente local (la provincia).

En estos términos, el uso que hacemos de la noción de territorio en este trabajo no pretende abordar el conjunto de los enfoques disponibles (geocrítico, relacional, geohistórico y/o práctico), sino más bien ilustrar la necesidad de analizar lo territorial para el caso de Tarapacá en el marco del proceso republicano experimentado durante el siglo XIX. Por ello, funcionalmente nos hemos quedado con una descripción y discusión del problema al alero del eje territorio-Estado, teniendo claro que "territorio" y "territorio nacional" configuran un problema histórico de envergadura que escapa a los objetivos, más bien preliminares, de estos comentarios al cuaderno de campo de Raimondi.

\section{* La expedición de Raimondi a la provincia DE TARAPACÁ: UN EJERCICIO ESTATAL DE CONS- TRUCCIÓN DE UN TERRITORIO NACIONAL}

Ya durante el reinado de Carlos III (1759-1788) ministros, como el economista Pedro Rodríguez de Campomanes y José de Gálvez, persiguieron impulsar el progreso mediante la aplicación de los métodos de la ciencia a la sociedad. Así, recopilando y analizando datos, se buscaron formas de promover el crecimiento económico, lo que se tradujo en el envío de una oleada de científicos y exploradores a las colonias americanas con el fin de obtener información sobre los recursos naturales, la geografía y los pueblos de las zonas económicamente estratégicas para los intereses de la Corona española y que se consideraban ubicadas en los perímetros de la sociedad colonial. Este proceso de reconfiguración política, militar y territorial es denominado por algunos estudios como la segunda conquista de América (Fisher 2000; Lynch 2004; Pietschmann 1996).

El conocimiento entonces, hacia la segunda mitad del siglo XVIII, se generó en clave económica, más aún cuando se instaló la idea de que para que España saliera de su estado de decadencia era indispensable desarrollar las ciencias, que en este caso se entendió como la exploración científica del territorio. De esta manera, con expediciones como las de José Celestino Mutis, Alejandro Malaspina o José Llano Zapata se buscó recopilar de manera sistemática información inédita sobre recursos naturales y nuevas formas de convertirlos en parte del desarrollo económico (Millones 2005).

En estos términos, la primera mitad del siglo XIX será heredera de esta concepción de las exploraciones científicas, pero se ajustará a la nueva característica derivada de los procesos independentistas, es decir, expediciones ya no ligadas a los intereses de la Corona española sino en referencia estricta con la configuración de los distintos territorios nacionales a través de dinámicas de colonización compulsiva por parte de las nacientes repúblicas, generando un nuevo ordenamiento espacial basado principalmente en las posibilidades de explotación del suelo y su viabilidad de incorporar las riquezas existentes como mercancía al mercado mundial, un propósito destinado sustancialmente a generar recursos económicos para implementar el Estado-nación y sus dispositivos de control y hegemonía?

Así, desde los inicios de la época republicana los Estados -con mayor o menor intensidad-implementaron formas para adquirir un saber más acabado de sus territorios, un proceso que transcurrió desde las meras aspiraciones hasta la constitución de prácticas, cuerpos profesionales e institucionalidad orientada al conocimiento exhaustivo y el monopolio estatal de la información racionalizada (Ruiz 2011: 13). Por lo mismo, la relación entre la mensuración del espacio y la construcción del Estado durante el ciclo decimonónico fue determinante. Por una parte, la progresiva definición de la propiedad y del territorio

\footnotetext{
7 La expansión de los Estado-nación y el nacionalismo en occidente en base al avance de la industria, la incorporación de mercados y la imposición de soberanías se aborda en Hobsbawm 2012.
} 
nacional graficaba los grados de avance de la instalación estatal; por otra, ponía al descubierto las concepciones de los grupos humanos sobre el territorio que habitaban, un elemento clave para establecer y sancionar qué era del Estado y qué no.

De ahí que para el caso particular de la república peruana, autores como Deborah Poole (2000: 183) señalan que será a partir de mediados de la década de 1840 que aparecerá el Estado bajo el liderazgo de Ramón Castilla, al abrir la discusión sobre el carácter nacional del Perú y su futuro económico, discusión coincidente con el impulso de comisiones exploradoras a la Amazonía, a Tarapacá y otros puntos alejados, de los que se comenzaban a visualizar y aceptar como partes del territorio patrio; proceso que significará el fin del sueño de unidad de Melgar al ser abandonado por la necesidad de construir un discurso de unidad nacional, utilizando la estadística, el mapa, la litografía y luego la fotografía como medidas mensurables de la modernidad, la ciencia y el progreso.

La adquisición de un saber útil del territorio, de este modo, a lo largo de la centuria decimonónica dio cuenta de la instalación de una visión desde arriba, destinada a convertir la tierra y sus recursos en mercancía homogénea, censada bajo una racionalidad positivista y ubicada en un territorio nacional que el Estado reconocía como propio y que, por lo mismo, entendía su sometimiento como legítimo (Ruiz 2011: 17-18). El espacio nacional, entonces, se dispuso y organizó mediante un único orden posible, donde el Estado proporcionaba eficacia a los rendimientos económicos y dominio efectivo de éste y la nación aportaba cohesión social e ideológica al mercado (Nadal 1990).

La construcción de un relato espacial sobre la nación tendrá su expresión más conocida en la publicación de los primeros tomos de la Historia del Perú Independiente (Lima 1868-1874) de Mariano Felipe Paz Soldán, quien durante dos décadas trabajó para lograr construir una versión integral de la nación peruana. ${ }^{8}$ Junto a la compilación de los

8 Cabe destacar que Mariano Felipe Paz Soldán se desempeñó como ministro de Estado en los gobiernos de Ramón Castilla y José Rufino Echenique por lo tanto estuvo en contacto directo y privilegiado con las expediciones científicas de Bollaert y Raimondi. Además fue director general de obras públicas y miembro corresponsal de la Sociedad de Prisiones de Filadelfia y de la Real registros materiales e históricos o los "hechos" que Soldán definió como "acciones políticas y militares" (Brading 2011: 230), se construyó una narrativa que fue, más que nacional, definitivamente estatal, lo que se puede verificar al contrastarla con el relato de su Atlas Geográfico del Perú publicado casi una década antes, en 1860.

Tal proceso de territorialización, complejo y expansivo, se llevará a cabo mediante dos tipos de empresas: los comerciantes que definirán las formas de usar y delimitar las regiones en complicidad con el aparato estatal, y las comisiones científicas dedicadas a desplegar un registro sistematizado y objetivado a efecto de recomendar o no el usufructo económico (Constanza 2010: 102).

La expedición de Raimondi a Tarapacá será del segundo tipo, inscribiendo de paso su nombre en la lista de ilustres viajeros y naturalistas - como Amédée Frezier, Thaddeus Haencke, Alcides d'Orbigny, Charles Darwin, John H. Blake, George Smith, William Bollaert y Francisco Puelma- que recorrieron los desérticos parajes de esta alejada región entre inicios del siglo XVIII y mediados del XIX.

En este contexto, gran parte del conocimiento que se tiene en la actualidad sobre la geografía y los recursos naturales existentes en Tarapacá, así como la adaptación de las personas a las difíciles condiciones medioambientales desérticas, proviene de las expediciones y viajes realizados por naturalistas, científicos y algunos empresarios aventureros que se adentraron en lo "vacío y desconocido" (González 2009: 6) que significaba esta región en esos años para estudiar, emprender negocios y registrar la mayor cantidad de datos posibles.

De este modo, el espíritu exploratorio permitió al Estado peruano adquirir un mayor conocimiento de un territorio sobre el cual poseía únicamente un imperfecto registro de sus dimensiones, distancias, ríos y principales obstáculos que dificultaban la toma de posesión de éste (López 2001: 576). A partir de la mejorada información aportada por dichos registros, tanto el Estado peruano como otros de Hispanoamérica, diseñaron e implementaron proyectos expansivos destinados a consolidar su control sobre todo del territorio, anhelo funcional y demandado por aquellas camarillas de empresarios vinculados a proyec-

Sociedad de Humboldt en México. 
tos extractivos de materias primas para la exportación, los que necesitaban la expansión y nacionalización de aquellos espacios periféricos y localizados más allá de las fronteras internas, con el fin de asegurar el derecho de propiedad sobre la tierra y los valiosos recursos descubiertos en ella, elementos indispensables que garantizarían entradas fiscales de creciente magnitud suficientes para permitir el fortalecimiento de sus aparatos estatales. ${ }^{9}$

En el caso particular de Raimondi, su recorrido preferentemente por la franja pampina ligada a la explotación del nitrato dará cuenta de la implementación de este "instrumento de gobierno" destinado a posibilitar una representación uniforme y general de esta región como un territorio del Estado (Nadal y Urteaga 1990; Sagredo 2009: 58-59), ejercicio que tuvo un antecedente preliminar en la expedición (más extendida e integral) realizada por William Bollaert en 1827 por mandato expreso de Ramón Castilla en su calidad de máxima autoridad política de la provincia de Tarapacá en aquel momento (Larraín 1975). Lo que hubo entonces entre los recorridos del explorador inglés y del naturalista italiano fue un correlato sustentado por dos agentes estatales, Castilla y Rufino Echenique, en torno a un proyecto político republicano que se aspiraba para el Perú, en el cual la lejana provincia de Tarapacá se insertaba únicamente a partir de su potencialidad económica como polo periférico de desarrollo. En este sentido, el Estado peruano impulsó políticas de apropiación y ocupación de la zona en respuesta a los intereses de banqueros y empresarios capitalistas que vieron en el salitre y el guano ubicados en el extremo sur del país recursos imprescindibles para la implementación de una economía minera e industrial (González 2012; Cueto 1989), capaces de sostener una renovación in-

\footnotetext{
9 Producto del incremento en la demanda de materias primas, territorios largamente ignorados por los centros de poder debido a su dificultad de acceso y extenuantes climas, fueron incorporados a la dinámica expansiva económica y esfera de influencia política estatal y nacional de las repúblicas hispanoamericanas. En las primeras décadas del siglo XIX, como ya lo ilustramos, tanto el Estado peruano, como el chileno y boliviano otorgaron incentivos públicos a viajeros y exploradores para que efectuaran recorridos conducentes a la mensura y racionalización del espacio y sus recursos (guano, caucho, salitre, bórax, plata, cobre).
}

tegral de la estructura administrativa, pilar del futuro proyecto civilista y modernizador de Pardo. ${ }^{10}$

Con ello el ejercicio estatal impulsado por estos personajes a través de la mencionadas exploraciones, se hizo parte del modelo instaurado por las reformas borbónicas de fines del siglo XVIII donde la ciencia fue un recurso utilitario para pesquisar posibilidades económicas del territorio nacional pretendido (Contreras y Cueto 2008: 642), además de plasmar un ejercicio instrumental destinado a la conformación de un espacio nacional integral que fuera validado y legitimado tanto por los agentes estatales como por los residentes locales al visualizar y constatar una referencia agencial de pertenencia.

Consecuentemente, se comenzó a afianzar una vinculación entre la exploración científica y la expansión estatal a razón, por una parte, de los requerimientos por reconocer y delimitar el territorio nacional y sus potencialidades económicas y, por otra, la disponibilidad de recursos aportados por la explotación del guano para contratar los servicios de algunos naturalistas que se encontraban en el Perú, tales como el suizo Johann Jakob von Tschudi, el peruano Mariano Eduardo Rivero y Ustariz, fundador del Museo Nacional de Arqueología, Antropología e Historia del Perú, el químico francés Héctor Davelouis, los marinos estadounidenses Lardner Gibbon, William Lewis Herndon y John Randolph Tucker que exploraron la Amazonía para el gobierno peruano; Tucker además fue creador y miembro de la primera Comisión Hidrográfica del Amazonas, entidad estatal destinada a indagar sistemáticamente las reservas de

10 El Estado peruano implementó un proyecto expansivo de ocupación soberana de los territorios periféricos, entre ellos Tarapacá, en consonancia con los intereses de la élite capitalista limeña que lo controló. Fue así como aquellos banqueros no industriales, que habían accedido previamente a la renta del guano quisieron ser también beneficiarios absolutos de la renta salitrera que, hasta la década de 1870 , no se hallaba en el horizonte de sus intereses. De este modo, apoyando el proyecto político de Manuel Pardo, Tarapacá y su riqueza salitrera fueron finalmente develados a un grupo (la oligarquía limeña) incapaz de transitar desde la acumulación primitiva del capital-dinero hacia la acumulación primitiva del capital industrial, lo que necesariamente significó la imposibilidad de que el Estado alcanzara la modernización de sus estructuras de poder y control (Bonilla 1974: 39). 
caucho, posibles trazados camineros para viabilizar la conexión y la comercialización de este recurso natural, y delinear los límites fronterizos con Brasil (Contreras y Cueto 2008: 642-643; Pease 1993: 26, 71-91; Larraín 1975; Núñez 1960).

La ciencia, en este entramado, aportó dos cosas: saberes que podían auxiliar al aparato estatal en tareas concretas (medir, conocer, describir, mapear, etc.) y sentidos simbólicos a su discurso legitimador y su proyecto de orden (Ruiz 2011: 21). Por lo mismo en exploraciones como las de Bollaert y Raimondi, es decir, mandatadas desde la agencialidad estatal, más que la precisión de las medidas lo relevante fue la capacidad de archivar información destinada a crear una "memoria administrativa" (Garavaglia y Gautreau 2011: 95) que hiciera visible el paisaje a la burocracia central (Craib 2000 y 2001 ), que no solo estaba asentada en Lima sino además era distante y desconocedora de los parajes tarapaqueños. En efecto, durante el siglo XIX el Perú fue un país conformado mayoritariamente por territorios a conocer tanto por el Estado como por el común de sus habitantes, un rasgo acentuado según Carlos Contreras y Marcos Cueto (2008: 635-636) por las fuerzas centrípetas provenientes desde Lima que consideraban los "espacios alejados" (en la sierra, en el altiplano, en la selva, en el desierto del extremo meridional) como ambientes vacíos e inhóspitos, provocando una débil integración nacional.

Producto de ello, no solo se precarizó el conocimiento e importancia de aquellas provincias más alejadas de los centros políticos-administrativos, económicos y urbanos, sino que también se les negó relevancia al actuar y costumbres de los habitantes de dichos espacios. Tal fue el caso de Tarapacá, la provincia peruana más austral en el siglo XIX, al no concentrar las "miradas de los intereses capitalistas limeños, fueran políticos o empresa-

11 Esta vinculación también formó parte de los procesos de expansión estatal de Bolivia y Chile. Por ejemplo, el gobierno boliviano financió la expedición del prefecto Agustín Palacios por los ríos del norte y noreste en busca de reservas de caucho y para la fijación de los límites internacionales con el Perú (López 2001). Por su parte, el gobierno chileno contrató a Rodulfo Philippi para que explorara el desierto de Atacama en busca de la ubicación del guano y los minerales de cobre y plata allí existentes (González 2011). riales" (González 2012: 103), a razón de su condición de territorio desconocido y habitado por indígenas, rasgos puestos en tela de juicio por la élite como partes del proyecto nacional de conformación de la sociedad y la República (Figueroa 2011).

Siguiendo los cánones del positivismo decimonónico de que la ausencia de civilización en aquellos espacios del territorio nacional no colonizados constituía simbólicamente desiertos, ${ }^{12}$ los indígenas y las poblaciones locales fueron considerados bárbaros, porque su cultura y organización política no estatal representaban el contrario de lo que se consideraba el alfa y omega de la civilización. De este forma, ignorando la existencia de población indígena y obedientes de la tradición hobbesiana de que el estado de naturaleza resultaría indeseable para el progreso, los Estados fundamentaron y materializaron a mediados del siglo XIX los proyectos de apropiación y colonización territorial de estos desiertos o espacios vacíos ${ }^{13}$ con una doble finalidad: en primer lugar, hacer coincidir los límites del Estado y la nación, ya que de este modo se consolidaría finalmente el fortalecimiento del sentimiento nacionalista y del aparato gubernamental y, en segundo lugar, permitir que las élites centrales expandieran el dominio metropolitano sobre aquellos territorios que paulatinamente comenzaban a concentrar la atención de los grupos económicos que, interesados en los recursos existentes, incentivaron múltiples proyectos de colonización interna por medios diversos, entre ellos la acción compulsiva a sangre y fuego, los procedimientos administrativosjudiciales y/o la atracción de inmigrantes preferente-

12 El contraste entre región focal y territorios "desertificados" simbólicamente se expresó de diversos modos: mientras el centro civilizado se describe con colores vivos, con una flora y fauna atractiva, cuyo clima resulta saludable y donde se encuentran símbolos de progreso, aquellos sectores habitados por bárbaros se identificaban como áridos, infestados de fauna nociva, deshabitados y representados habitualmente por un cactus, planta típica del desierto (Rajchenberg y HeauLambert 2008: 181).

13 El criterio de apropiación y su legitimación, suponía que la estatalidad se imponía sobre la nada. Así se excluía de la discusión el tema de la cuestión indígena, situando al desierto como el escenario óptimo para la implementación de parámetros y formas de organización y explotación características del mundo capitalista occidental civilizado (Lois 1999). 
mente europeos (Rajchenberg y Heau-Lambert 2008; Arriaga-Rodríguez 2013).

De este modo, la expedición de Raimondi implicará una inflexión en torno a la despreocupación estatal asentada en Lima de un territorio en disputa. ${ }^{14}$ Con la disponibilidad de recursos económicos aportados por el guano, ${ }^{15}$ y ante la necesidad de auscultar otras posibilidades de explotación de recursos naturales equivalentes, a mediados del siglo XIX se toma la decisión de patrocinar una exploración científica destinada a la elevación de informes sobre los depósitos de nitrato de soda y la emergente industria salitrera tarapaqueña que se hallaba en manos, ni más ni menos, de un grupo de empresarios locales y extranjeros "dispuestos a arriesgarse a invertir en un desierto que era todavía no solo un riesgo, sino un misterio" (González 2011: 160-161), gozando por lo mismo de una plena libertad de trabajo para descubrir el caliche, ${ }^{16}$ elaborarlo, exportarlo y capitalizar sus utilidades en un territorio de geografía amplia, difícil y no plenamente incorporado a lo peruano (Paniagua 2009: 58).

En este estado de cosas, la expedición de Raimondi se enmarcó dentro de un ejercicio que buscó afanosamente construir un Estado nacional mediante la integración de su territorio a través de la acción conjunta del conocimiento científico, el desarrollo económico y la intervención político-administrativa (López-Ocón 2001: 11-12), armonizando un aspecto político con uno económico en

14 Este rasgo distanciará los alcances del recorrido de Antonio Raimondi respecto al de William Bollaert. Si bien ambos son producto de un ejercicio estatal (por iniciativa de Ramón Castilla como subprefecto de la provincia de Tarapacá en un caso y por disposición de José Rufino Echenique en su investidura de Presidente de la República en el otro), lo recabado por Raimondi tendrá como destino la élite del aparato central instalado en Lima y con ello se situará lo nacional, mientras que lo registrado por Bollaert se dirigirá a los intereses de quien dirigía la administración de una alejada provincia en un momento de mayores incertidumbres que certezas, por tanto su impacto será más bien local, no obstante que su expedición fue más completa, extendida y sistemática en los registros.

15 En torno al guano, Raimondi ubicó 28 depósitos de este recurso natural, proveyendo un volumen cercano a 22 millones de toneladas de una gran calidad y altamente demandados en Europa como abono (Raimondi 2003).

16 Caliche, nombre que recibe el salitre en bruto (Raimondi 1853: 6). cuanto a la posición (el lugar y no lugar a la vez) de la provincia de Tarapacá en el entramado del proyecto republicano peruano en un período, la primera mitad del siglo XIX, en el cual las fronteras nacionales meridionales o no estaban plenamente establecidas, o eran desconocidas, $\mathrm{O}$ simplemente eran disputadas.

Vale recordar, en primer término, cómo una buena parte de la inestabilidad política del Perú de los decenios de 1830 y 1840 tuvo que ver con la discusión acerca de si el sur, entre ellos Tarapacá, debía ser parte de un territorio peruano único, o parte de un Estado Sud-peruano partícipe de una confederación con un Estado Nor-peruano y Bolivia para formar una gran nación andina, o bien integrarse a una República de Bolivia plenamente independiente. ${ }^{17}$ No por nada en 1831 en El Republicano de Arequipa se comentaba que ante los afanes territoriales de Perú por el área de Copacabana, a las riberas del lago Titicaca, se podía indemnizar a Bolivia con los "altos de Tarapacá", ${ }^{18}$ o que en 1839 El Comercio de Lima informara que "muchas personas" han "asegurado que de La Paz se habían remitido comisionados a las provincias de Tacna y Tarapacá con el objeto de sublevarlas y unirlas a aquella República"; ${ }^{19}$ un escenario que se agudizará tanto en 1841 al invadir la provincia una fuerza militar boliviana comandada por el teniente Ilarión Ortiz, ${ }^{20}$ como al año siguiente cuando el coronel boliviano José María García no solo toma el pueblo de Tarapacá, sino se autodesigna como comandante general político y militar de la provincia, desconociendo con ello la autoridad del subprefecto peruano Félix Calixto Gutiérrez de la Fuente. ${ }^{21}$

También, en segundo término, el dar cuenta de la emergencia de una reivindicación regional que ponía en cuestión la integración de la provincia de Tarapacá y sus intereses a la república peruana dominada por la élite limeña. Por ejemplo, en abril de 1840 el mencionado

17 Respecto a la Confederación Perú-Boliviana y los alcances políticos en juego, ver: Donoso y Rosenblitt 2011.

18 El Republicano, Arequipa 5.03.1831, p. 2.

19 El Comercio, Lima 22.05.1839, p. 2.

20 Archivo Regional de Tacna (en adelante ART), Prefectura, Comunicaciones Recibidas de la Subprefectura de Tarapacá 18371868, Legajo 1, Cuaderno 6, Oficio del Subprefecto de la Provincia Calixto Gutiérrez de la Fuente al Prefecto del Departamento, Iquique 4.01.1841, sin foj.

21 El Republicano, Arequipa 29.01.1842, p. 34. 
subprefecto Gutiérrez de la Fuente le señalará al prefecto del departamento de Moquegua que la "situación actual de la Provincia es notoriamente lamentable". ${ }^{22}$ Cinco años más tarde, en marzo de 1845 , el subprefecto Carlos Carpio reiterará los dichos de su antecesor al informarle al prefecto que el "estado actual de la Provincia es deplorable, por que subsistiendo ella de una única industria de los salitres, este fin se halla limitado hoy al trabajo que sostienen los salitreros adeudados de los especuladores de Iquique en este ramo". ${ }^{23}$ Una década después, el asunto seguía exactamente igual, pero a esa altura la distinción será ya plenamente política si tomamos en cuenta el tono de un corresponsal iquiqueño del diario El Comercio de Tacna al dar cuenta en 1856 sobre la situación por la que atravesaba la "apartada" provincia al punto que "gime y llora de verse olvidada completamente del Gobierno"; 24 del mismo modo lo mencionado en 1859 por el corresponsal de El Correo, editado también en Tacna, respecto a que "Iquique, uno de los puertos más interesantes de la República" y que le debía su "adelanto al impulso que naturalmente le concede la riqueza natural”, se encontraba "relegada al olvido de los Gobiernos, más bien oprimida que protegida por ellos". 25 Mismos términos que utilizará el empresario salitrero Juan Williamson en 1860 al manifestar que "una parte de la responsabilidad" de la "oscuridad" de la economía de la provincia "pesa directamente sobre el Gobierno, si en realidad Tarapacá tiene el derecho de considerarse de importancia como provincia y parte integral de la república" (Williamson 1860: 52). Cerrando el ciclo, nueve años más tarde, en 1868, Luciano Benjamín Cisneros, enviado por el gobierno para verificar la situación en que se encontraba la zona después del terremoto y tsunami de ese año, afirmará que los residentes tarapaqueños convivían entre "la riqueza que allí existe" y la "incuria de los Gobiernos que han visto con desdeñosa mirada lo que una administración solícita e inteligente habría explotado con provecho", provocan-

22 ART, Prefectura, Comunicaciones Recibidas de la Subprefectura de Tarapacá 1837-1868, Legajo 1, Cuaderno 5, Oficio del Subprefecto de la provincia Calixto Gutiérrez de la Fuente al Prefecto del Departamento, Tarapacá 4.04.1840, sin foj.

23 ART, Prefectura, Comunicaciones Recibidas de la Subprefectura de Tarapacá 1837-1868, Legajo 1, Cuaderno 12, , Oficio del Subprefecto de la provincia Carlos Carpio al Prefecto del Departamento, Tarapacá 30.03.1845, sin foj.

24 El Comercio, Tacna 10.05.1856, p. 2.

25 El Correo, Tacna 17.05.1859, p. 2. do una "punible negligencia haciendo fructuosos para el país los gastos que demanda un puerto que solo tiene de nacional hallarse en territorio peruano" (Benjamín Cisneros 1868: 48).

Ya sea por el lado de la adscripción territorial o por el de la visión de los residentes locales de que no estaban necesariamente (o plenamente) integrados al proyecto nacional, más la necesidad de la administración central de buscar un recurso que reemplazara la renta guanera, la expedición de Raimondi catalizó un escenario complejo y puso por primera vez a Tarapacá, mucho más que Bollaert, en el meollo de la agencialidad estatal peruana. Con ello viabilizó, no sin dificultades, que en el imaginario de la sociedad oligárquica limeña (que controlaba la banca y los gobiernos nada menos) se reprodujera un sentido de propiedad sobre esta alejada y desértica área geográfica, como a la vez permitió que la provincia más meridional comenzara a ser incluida, aunque parcial y precariamente, en el ordenamiento territorial del Estado-nación peruano (Medina 2006: 15), un proceso que quedó inconcluso a raíz de la guerra con Chile iniciada en 1879 .

\section{* RAIMONDI y SU imAgen DE TARAPACÁ}

Los territorios se fundan en narrativas territoriales articuladas en un proyecto político que busca no solamente describir sino ejercer dominio en función de una colonización interna sobre éstos. Consecuentemente, el territorio es una manera de aprehender, conceptualizar y apropiarse del espacio donde se vive o se cree propio, un proceso que se despliega a través de las experiencias en el marco de dinámicas de aprendizaje social (Tuan 2001). El territorio como concepto geográfico, entonces, ayuda a la interpretación y comprensión de las relaciones sociales vinculadas de una u otra forma a la dimensión espacial. El concepto es flexible, pero durante los inicios del siglo XIX el territorio se convirtió en un soporte fisiográfico de los Estados nacionales, influenciando la cartografía y por lo tanto la construcción del paisaje imaginado como variable social. Con el avance del capitalismo y la necesidad del comercio y la industria de un conocimiento más específico de los recursos, la región emergió como un quiebre con respecto al determinismo geográfico de la construcción territorial homogénea, incorporando así a los Estados nacionales el ideal de mosaico, fijando discursos en torno a una idea de futuro relacionada con 
la incorporación de los recursos en un mercado (Llanos 2010). Creemos que el estudio de Raimondi obedece a este paradigma, el que se construye a través del concepto complementario de territorio-región.

En cuanto al espacio, debemos entender que se articula, por una parte, como un concepto más abstracto en el que podemos ubicar los objetos físicos o humanos $y$, por otra, que se construye históricamente. ${ }^{26} \mathrm{Y}$ si bien son variadas las representaciones que se construyen sobre el espacio, algunas de ellas se institucionalizan en ciertos dominios de validez que son asumidos según los intereses en juego (Lois 1999), resultando de ellos tramas de poder como a la vez construcciones materiales y simbólicas (D'Amico et al. 2013: 60). Ahora bien, el espacio geográfico como nomenclatura económico-social surge durante el siglo XIX a partir de un discurso dotado de una intencionalidad económica y simbólica (Capel 2016). La necesidad de representarlo en mapas, diarios de viajes y cartografías tuvo como fin la sistematización de los hallazgos encontrados. El espacio empezó a ser el elemento de donde se obtenían los recursos para que el desarrollo capitalista se pusiera en marcha (López y Ramírez 2012) y en donde la importancia del conocimiento de los espacios geográficos nacionales pasó a ser estrictamente política.

A la fecha de la visita de Raimondi, Tarapacá carecía de una narrativa territorial regional asumida a plenitud tanto desde el Estado como desde la sociedad local, provocando más bien lejanía a condición de su carácter periférico en lo geográfico, lo político y lo económico. Era parte del Perú, sin embargo esta pertenencia estaba condicionada fuertemente por todos los procesos de indefinición política del momento, también por el imaginario de la élite y de la burocracia asentada en Lima - cada vez más predominante en el ejercicio del control del proyecto republicano peruano- para quienes los parajes tarapaqueños estaban más allá de lo mensurable y, por último, por los propios residentes que constataban cotidiana-

26 Espacio, territorio y región constituyen categorías básicas de la definición de un proyecto nacional. Ninguno de ellos representa conceptos absolutos, neutros, ni desprovistos de contenido, sino que por el contrario, son expresiones dinámicas de la espacialización del poder, el saber y las relaciones socioeconómicas de cooperación y/o conflicto dadas en un momento determinado. Respecto del análisis de éstos, ver: Montañez y Delgado 1998; Nogué i Font 1989. mente cierta autonomía en sus quehaceres respecto del ejercicio estatal, lo que se traducirá en una sensación de abandono que, como vimos, perdurará por largo tiempo, a tal punto que se traspasará al período de la administración chilena de esta región marcando - como un factor de continuidad- la relación Estado-región (Castro 2005).

Una buena prueba de lo anterior es que los antecedentes recopilados con prolijidad y amplitud por William Bollaert en 1827 a solicitud de Ramón Castilla, registro que contempló entre otros asuntos un extendido detalle de la incipiente y potencial industria salitrera (Larraín 1975), no tuvieron suficiente eco en el aparato estatal peruano de la época como para delinear una temprana territorialidad nacional a razón de una incorporación efectiva de esta zona. Será recién a partir de los requerimientos rentistas y la búsqueda de un recurso suplente del guano a mediados del siglo XIX que aparecerá Tarapacá y su salitre en la geografía del Perú, y es la expedición de Antonio Raimondi el instrumento para validar este interés y el comenzar a agencializar lo peruano para legitimar la propiedad nacional del recurso y del espacio donde estaba, y de este modo minimizar las potestades adquiridas en los hechos (por acción propia y por omisión estatal) por quienes habían asumido los costos de intentar sacar adelante la minería salitrera (extranjeros y empresarios locales) a pesar de la indiferencia de los gobiernos de la época a sus requerimientos (Williamson 1860).

De ahí que la narrativa contenida en los notas de campo de Raimondi se articulará en tres dimensiones centrales: 1) el dar cuenta (más bien ratificar lo señalado por Bollaert y otros antes que él, pero que no habían sido mandatados oficialmente por la máxima autoridad política del país) que el salitre era una alternativa real como mercancía incorporable al mercado mundial y por tanto generadora de renta; 2 ) remarcar los rasgos desérticos de Tarapacá; 3) dar cuenta del paisaje y de las actividades económicas ligadas a él.

Respecto a lo primero, para Raimondi el asunto no solo se traducía a una cuestión de viabilidad económica en cuanto a la calidad del salitre y el volumen disponible, sino de modo prioritario a la incorporación de tecnología para optimizar los resultados económicos y solucionar el inconveniente del abastecimiento de agua potable. Con ello establecía una única recomendación plasmada en su 
libreta: "Para producir por este medio 20 quintales de salitre se consumen 4 quintales de carbón, el cual se podría economizar mucho si se hubiese a calentar los fondos por medio del vapor producido por una caldera y cuyo vapor se podría utilizar condensándolo para obtener agua dulce que falta en este lugar" (Raimondi 1853: 9).

Con esta afirmación, sin duda su propósito fue el de remarcar que el salitre, a diferencia del guano, requería mayor capitalización para ser eficiente y rentable su explotación, una preocupación manifestada recurrentemente por los empresarios mineros locales desde al menos la década de 1830 (Williamson 1860) y que seguramente Raimondi tomó conocimiento a través de las conversaciones que tuvo con distintos personajes, incluyendo al propio William Bollaert, con quien visitó Huantajaya, desde que llegó a Iquique en la tarde del 18 de noviembre de 1853 .

En cuanto a acentuar los rasgos desérticos de Tarapacá, no solo tuvo que ver con su propia impresión de lo agreste, después de todo recorrió la parte más árida de toda la provincia, sino igualmente con el ser partícipe de una percepción ya instalada en distintos ámbitos institucionales del Perú sobre los desiertos. En efecto, en el siglo XIX el desierto en tanto una categoría mensurable desde y para el Estado, más que tener que ver con un rasgo medioambiental fue parte de un programa político que buscó "vaciar" discursivamente ciertos espacios para representarlos como lugares disponibles (Lois 1999 y 2007; Navarro Floria 2002: 141-142). De esta manera, en el entramado narrativo y descriptivo de Raimondi emergerán como elementos centrales conceptos tales como desolación: "Alrededor de este pueblo [Rinconada] se hallan algunos árboles de tamarugo, lo que le quita aquel aspecto triste y árido que se nota en muchas partes de esta gran pampa" (Raimondi 1853: 13. El subrayado es nuestro), y carencia de vegetación: "en la quebrada [de Tarapacá] no se ve ningún indicio de vegetación sino que un poco más adelante del alto de una pequeña costa se descubre un valle más bajo y el pueblo de Guaraciña" (Raimondi 1853: 51. El subrayado es nuestro).

Consecuentemente, el desierto no se reducirá en aquella época únicamente a un espacio necesario de mensurar por sus carencias, es decir, a una apropiación únicamente utilitaria, sino igualmente a una asimilación simbólica que tendrá su soporte en georreferencias almacenadas en representaciones y esquemas cognitivos que lo describirán preferentemente como un lugar baldío y vacío aunque estuviese habitado por indígenas, colonos, mestizos, lugareños o extranjeros (Rajchenberg y Héau-Lambert 2007: 38-39 y 2008: 179-181). Entonces el concepto de deshabitado se remarcará con reiteración, salvo algunas excepciones, respecto a cada localidad visitada: "La Rinconada es un pequeño pueblo que ahora está deshabitado y sus casas ya no tienen techo"; "Challapozo consiste en una sola casita habitada y en alguna otra destruida"; "Challapocito es formado por una sola casita"; "Esta pascana [Pozo de Quinto] está formada por una casita y dos pozos"; "Quillagua es un pequeño pueblo situado sobre la orilla del río Loa"; Maní "que es un pueblo formado solamente por dos o tres casitas abandonadas"; "Huatacondo. Este es un pueblo un poco grande"; "Este pueblo [Guaraciña] que ahora es casi enteramente deshabitado..." (Raimondi 1853: 12-13, 15, 19, 24, 33, 36, 39, 51). Por cierto, la excepción no será muy distante de la condición anterior: "La Tirana, de los pueblos situados en la pampa, es el mejor, tiene algunas casas un poco decentes y bien construidas" (Raimondi 1853: 49).

Llevando a cabo excavaciones, indagatorias y bosquejos de todo lo que veía, y analizando plantas, fauna, flora, suelo y minerales, Raimondi corroboró no solo que el territorio más meridional (y menos ligado) del Perú poseía un enorme potencial (no solo por el salitre, sino también por la sal, el bórax y la arcilla existentes en diferentes concentraciones y ley) que debía ser aprovechado por el Fisco peruano, sino igualmente constató que la economía local debía diversificarse con apoyo del Estado. En estos términos, por una parte dirá la "excavación y purificación del nitrato de soda (salitre) constituye el trabajo de todos los habitantes de este lugar" (Raimondi 1853: 6. El subrayado es nuestro); por otra, establecerá -al describir los cultivos de melones, sandías, zapallos, trigo, cebada y alfalfa que había logrado implementar Mariano Morales en el trayecto de Challapozo a La Noria-que:

Sería una muy buena cosa el estimular a este hombre que ha pasado tantos trabajos y sacrificios en los primeros años y porque ha dado un ejemplo a los de la provincia al hacer producir un terreno que antes era enteramente estéril. Quiera Dios que los otros sigan su ejemplo cultivando estos terrenos que venderá a muy rica esta provincia y no se vean obligados a emigrar como los que traba- 
jaron minas siendo la agricultura permanente y no temporaria como las minas del salitre y el borato" (Raimondi 1853: 2223. Los subrayados son nuestros).

Esta observación de Raimondi es notable, ya que será el punto de partida de una percepción que se transformará con el tiempo, a raíz de la despreocupación de los gobiernos centrales de Perú y Chile por el devenir económico de este alejado territorio, en una demanda de desarrollo regional que los tarapaqueños sustentarán con fuerza, al menos, hasta la década de 1930. Más de ocho décadas en donde madurará la necesidad de solventar una actividad agrícola a gran escala en oposición a las pretensiones rentistas estatales, peruanas primero y chilenas después, centradas en la exclusiva explotación del salitre (Castro 2005: 25-29, 63-91).

Junto con lo anterior, la imagen de Tarapacá que desplegará Antonio Raimondi se ligará a la interacción humana con el paisaje y los recursos de la pampa salitrera. Así, por ejemplo, le llamará la atención la reutilización de la capa de caliche que se removía para descubrir una superficie menos salina destinada al cultivo, generando un uso sustentable y eficiente de los materiales disponibles: “y no es pues enteramente inútil este caliche porque sirve como material de construcción para fabricar casas cerca de los lugares cultivados" (Raimondi 1853: 22); como también el uso de la caliza y la traquita en el oasis de Pica con el mismo propósito:

Uno de los materiales principales de construccion es la tiza que se halla esparcida sobre el terreno en pequeñas masas como ya hemos notado en varios lugares, allí se muelen estas piedras y por medio de un chimbalete se mezclan. Despues con arena y agua se hace una especie de argamasa que después de algún día toma una consistencia y solidez muy grande; es a notar que por 405 días esflorece sobre estas construcciones una especie de sal que se tiene cuidado de barrer hasta que cesa de esflorescencia. Con esta mezcla se hacen tambien ladrillos bastantemente sólidos; de modo que con esta tiza y algunas cañas se fabrican las casas.

Las construcciones que demandan mucha solidez además de estos materiales se emplea la traquita compacta que se saca de muy cerca del pueblo; $y$ con estos materiales se ha construido la torre y la iglesia" (Raimondi 1853:42).
El deterioro de los bosques de tamarugos y la actividad económica asociada a esta tala también será recurrente en su descripción, destacando este rasgo no solo en distintos pasajes de su libreta: "[en Challapozo el terreno es] suelto [y] cubierto en algunas partes de grama y de algunos tamarugos que en gran cantidad existían en otro tiempo, más que en el día han disminuido mucho por el corte que hacen o para hacer carbón o para transportarlos como leña a las oficinas del salitre", "[saliendo de Challapozo] lo que extraña mucho es ver la cantidad de troncos de tamarugo que se encuentran enterrados, lo que hace suponer hayan sido estos lugares en otro tiempo un monte muy espeso. Ahora sirven estos troncos a los señores que hacen este comercio transportándolos a las oficinas de salitre, principalmente a La Noria Nueva, adonde lo pagan de 15 a 17 pesos cada 100 arrobas", "[de La Tirana a Tarapacá] casi toda la pampa indica por sus restos haber sido un monte de tamarugos, retamas y pillagas" (Raimondi 1853: 15, 21-22, 50); sino también resaltando la presencia de un personaje obviado por otros observadores a condición de una mirada menos prolija y compenetrada, el del leñador: "[en Challapozo hay una] sola casita habitada [que es] la mansión de nuestro guía que habita alli cortando leña de algunos tamarugos que existen en aquellas serranías", "[en Pozo Quinto en] el día se hallan en los alrededores muchas chozas en la que viven varios leñadores" (Raimondi 1853: 15, 25). ${ }^{27}$

Así, para Raimondi, el paisaje humano de la pampa salitrera de Tarapacá y las áreas aledañas estarán ligados al minero, al aguatero y al arriero, pero también al agricultor que sacaba frutos en las tierras calichosas, y al leñador. Esta composición, perceptible desde Tarapacá y a la vez poco nítida desde fuera, denotará no solo la configuración demográfica y la adaptación al desierto, sino igualmente el origen de una agencialidad regional que, a medida que avanzaba la conformación territorial del proyecto republicano peruano, se plasmará como reivindicativa y refractaria a los intereses estatales dominados por la élite oligárquica limeña, especialmente civilista, de situar la zona como un mero "lugar" proveedor de una mercancía para el mercado mundial.

27 Junto con la explotación del bosque, o monte, Raimondi resaltará el hecho de la preocupación de las autoridades locales por "prohibir el corte bajo pena de una multa porque de otro modo no habría al presente existido un solo árbol cortándose para leña y venderla a las oficinas del salitre" (Raimondi 1853: 50). 


\section{* Consideraciones finales: la trama del po- DER Y LA POSICIÓN SUBALTERNA DE TARAPACÁ}

El viaje de Antonio Raimondi a Tarapacá no solo implicó de su parte un laborioso trabajo de campo, sino también un primer ejercicio estatal, ${ }^{28}$ mandatado desde Lima e impulsado por los afanes rentistas que provocó que la región más meridional comenzara a aparecer en la geografía nacional peruana. ${ }^{29}$ En efecto, si bien la tarea principal de esta expedición consistía en brindarle al gobierno parámetros técnicos e información confiable sobre la calidad, cantidad y ubicación de los recursos mineros posibles de transformar en renta (salitre y bórax), además contribuyó al conocimiento y desenvolvimiento de la vida de los habitantes de un territorio considerado en la primera mitad del siglo XIX como desconocido e inhóspito.

Dicha información cobraría gran significación en la década de 1870, al iniciarse para el Perú una traumática transición de una economía basada íntegramente en el guano a una que intentó sustentarse, bajo la misma lógica rentista, en la explotación del salitre tarapaqueño buscando sostener los intereses capitalistas limeños que requerían reproducir y expandir culturalmente sus instituciones y el proyecto nacional civilista (Orrego 2005: 217; González 2012: 101-103 y 2013: 41; Mc Evoy 1994 y 1997; Mücke 2010). ${ }^{30}$ Más aun cuando, como lo sostiene Carlos Flores (2000: 47), bajo los gobiernos civilistas la vinculación de Lima con Tarapacá (y por Lima debemos entender la élite civilista que controlaba el poder económico y político mediante la banca y el gobierno) estuvo

28 La expedición de Raimondi a la provincia de Tarapacá constituyó la continuación inmediata del primer encargo gubernamental que se le encomendaría en su calidad de competente hombre de ciencia a las islas de Chincha. Tras haber recorrido por un lapso de 40 días en compañía del químico itálico José Eboli las islas para calcular las reservas de guano existentes, Raimondi procedió a recorrer Tarapacá para reconocer y estudiar el terreno, y en particular los yacimientos de salitre presentes en la zona como parte del encargo del gobierno (Seiner 2003: 521; Raimondi 1874: 142).

29 Estos afanes rentistas del aparato estatal ligado a la explotación del guano y el salitre han sido largamente discutidos por la historiografía peruana. Al respecto ver: Bonilla 1974 y 1980, Orrego 2005, Contreras y Cueto 2000.

30 La relación entre Raimondi y el civilismo se aborda en: Mc Evoy 2013: 269-283. condicionada a la reivindicación del territorio tarapaqueño como "dominio del Estado".

Entonces la exploración de Raimondi a Tarapacá fue en estricto rigor un ejercicio de Estado más que un recorrido propio de un naturalista y sus afanes ilustrados, no solo por ser mandatada y financiada por el Presidente de la República, no solo por responder a los intereses del gobierno, sino también porque en lo sustancial se restringió en su recorrido básicamente a inspeccionar lo encomendado, es decir, la zona salitrera, indagar la composición química del salitre, las características de los yacimientos de nitrato y la modalidad de extracción, dejando de lado el altiplano y gran parte de la precordillera, territorios que seguramente habría inspeccionado si su visita a Tarapacá hubiese respondido estrictamente a sus inquietudes como naturalista. ${ }^{31}$ Tal omisión será el indicio, por una parte, del despliegue de un dispositivo estatal ${ }^{32}$ que reconocerá en los resultados de la expedición de Raimondi la confirmación del potencial del salitre como mercancía y, por otra, un primer interés por llevar a cabo una ordenación administrativa del espacio tarapaqueño. En efecto, no solo a partir de mediados

31 Para reafirmar este punto, es necesario recordar que la exploración a Tarapacá no fue la única que financió el gobierno peruano a Raimondi, sin embargo a diferencia de aquéllas, en las que el naturalista italiano autónomamente trazó el trayecto y definió la agenda del recorrido, la realizada a la provincia más meridional del Perú y la efectuada a las guaneras de las islas Chincha meses antes, fueron las únicas que se acotaron estricta y rigurosamente a lo establecido en el contrato y que decía relación con una preocupación del Estado peruano por saber con cierta exactitud el potencial y reserva de los recursos naturales que sustentaba (el guano) o podía sostener en el futuro mediato (el salitre) la renta fiscal, principal mecanismo de financiamiento de la organización pública y su expansión.

32 Por dispositivo, entendemos una estrategia que busca configurar una herramienta utilizable en el campo de las relaciones de poder (el control social, político y económico), las prácticas sociales y los modos de gobernar que instalan las formas de ser, hacer y conocer en un contexto histórico determinado. De esta manera, el dispositivo estatal es un medio, o soporte, por el cual el Estado organiza y sanciona referencialmente el lugar que ocupan las relaciones que conducen a una verdad que se convierte en poder. En nuestro caso la "exploración" (la herramienta) cuyo "conocimiento" generado (el saber) determina o sujeta una "verdad" (el desierto como un vacío). Sobre los alcances epistémicos del concepto dispositivo ver: Agamben 2011, Deleuze 1990, Foucault 2002 y 2008, Moro 2003. 
del siglo XIX el Estado peruano (o lo que había de él) le pondrá mayor atención a la minería del salitre, lo que no significará necesariamente una preocupación mayor por la necesidades regionales (González 2012), sino que la agencialidad se dirigirá a la pampa y la costa (donde estaba la riqueza salitrera y los puertos para sacarla hacia los mercados mundiales) mediante la instalación de reparticiones y funcionarios, provocando a partir de este hecho un crecimiento demográfico de toda esta área en desmedro de la zona andina, como el desplazamiento del poder político local, ${ }^{33}$ lo que se traducirá -entre otras decisiones - en la habilitación de Iquique como puerto mayor primero y capital provincial después, la declaración de Pisagua como puerto menor y la habilitación de las respectivas aduanas.

En este sentido, lo que se desplegó a partir de la expedición de Raimondi fue una ocupación estatal de Tarapacá estrictamente funcional en una época, además, donde la economía peruana se hallaba fuertemente ligada a los préstamos financieros de bancos y casas comerciales extranjeras y nacionales, préstamos que tuvieron por garantía el guano y el salitre. Consecuentemente, estos recursos naturales se volvieron sinónimo del presupuesto nacional a causa de su necesidad de saldar la deuda pública con los acreedores internos y externos, mantención de las Fuerzas Armadas y del creciente aparato burocrático.

33 Sobre este cuestionamiento en particular ver: Exposición que los habitantes de Tarapacá hacen al Congreso de 1874 por motivo de la traslación de la capital a Iquique, Iquique 1874 .
Desde este momento, la década de 1850, Tarapacá adquirirá paulatina y crecientemente importancia económica, aunque políticamente seguirá ignorada por la élite asentada en Lima, provocando que las relaciones de poder locales y las aspiraciones de la sociedad regional en su conjunto se vieran sometidas a ciertas tensiones producto de un ejercicio fiscal marcado por el rentismo, ${ }^{34}$ un sesgo que será profundizado por el Estado de Chile cuando pase a administrar soberanamente este territorio como resultado de la Guerra del Pacífico (Castro 2005).

Por último, debemos señalar que si bien sostenemos que la obra de Antonio Raimondi respondió a la construcción económico-política de la república peruana durante la segunda mitad del siglo XIX, el conocimiento o alcance de sus registros tomará mayor importancia luego de la Guerra del Pacífico (1879-1883), hito bélico definido por los intelectuales de la época como el peor golpe cultural a la patria (Brading 2011: 257). Es así como, por ejemplo, la generación de José de la Riva-Agüero y Osma (1885-1944) rescatará las compilaciones geográficas, los registros, relatos y narraciones epocales para reconstruir el "alma nacional peruana", despertando el nacionalismo bajo la inspiración de Renan, Michel y Carlyle.

\section{* Agradecimientos}

Estos comentarios, como la transcripción de la libreta de Raimondi, forman parte del Proyecto FONDECYT 1140159 .

\footnotetext{
34 Otros aspectos de la tensión entre la élite limeña civilista y rentista y los habitantes de Tarapacá en: Una justa contestación. Los verdaderos tarapaqueños, Iquique 1877.
} 


\section{* Referencias citadas}

\section{Fuentes inéditas}

RAIMONDI, A. 1853. Provincia de Tarapacá. Archivo General de la Nación del Perú, Colección Antonio Raimondi, Libreta $\mathrm{N}^{\circ} 2$.

ARCHIVO REGIONAL DE TACNA (ART), Prefectura, Comunicaciones Recibidas de la Subprefectura de Tarapacá 1837-1868, Legajo 1, Cuaderno 6.

ARCHIVO REGIONAL DE TACNA (ART), Prefectura, Comunicaciones Recibidas de la Subprefectura de Tarapacá 1837-1868, Legajo 1, Cuaderno 5.

ARCHIVO REGIONAL DE TACNA (ART), Prefectura, Comunicaciones Recibidas de la Subprefectura de Tarapacá 1837-1868, Legajo 1, Cuaderno 12.

\section{Impresos y periódicos}

Exposición que los habitantes de Tarapacá hacen al Congreso de 1874 por motivo de la traslación de la capital a Iquique. Imprenta La Opinión Nacional, Lima 1874.

Una justa contestación. Los verdaderos tarapaqueños. Iquique 1877.

El Comercio, Lima, 22.05.1839.

El Comercio, Tacna, 10.05.1856.

El Correo, Tacna, 17.05.1859.

El Republicano, Arequipa, 5.03.1831 y 29.01.1842.

\section{Referencias citadas}

AGAMBEN, G. 2011. ¿Qué es un dispositivo? Sociológica 26(73): 249-264.

AMIN, A. 2000. The economic base of contemporary city. En $A$ companion to the city, G. Bridge y S. Waston (Eds.), pp. 115-129. Blackwell, Oxford.

ARRIAGA-RODRÍGUEZ, J. C. 2013. Tres tesis del concepto frontera en la historiografía. En Tres miradas a la historia contemporánea, G. Gurza Lavalle (Coord.), pp. 9-47. Instituto Mora, México.

BASADRE, J. 2014. Historia de la República del Perú (1822-1933). Tomo 4. El Comercio y Producciones Cantabria, Lima.
BENEDETTI, A. 2011. Territorio: concepto integrador de la geografía contemporánea. En Territorio, lugar, paisaje. Prácticas y conceptos básicos en geografía, P. Souto (Coord.), pp. 11-82. Editorial de la Facultad de Filosofía y Letras, UBA, Buenos Aires.

BENJAMÍN CISNEROS, L. 1868. Apuntes sobre la comisión al Sur por el ex Ministro de Beneficencia. Imprenta del Estado, Lima.

BERMÚdEZ, O. 1963. Historia del Salitre desde sus orígenes hasta la Guerra del Pacífico. Ediciones de la Universidad de Chile, Santiago.

BONFIGLIO, G. 2004. Antonio Raimondi. El mensaje vigente. Universidad de Lima y Banco de Crédito del Perú, Lima.

BONILLA, H. 1974. Guano y Burguesía en el Perú. Instituto de Estudios Peruanos, Lima.

BONILLA, H. 1980. Un siglo a la deriva. Ensayos sobre el Perú, Bolivia y la Guerra. Instituto de Estudios Peruanos, Lima.

BOZZANO, H. 2009. Territorios Posibles. Procesos, lugares y actores. Lumiere, Buenos Aires.

BRADING, D. 2011. Profecía y patria en la historia del Perú. Fondo Editorial del Congreso del Perú, Lima.

BRENNER, N. 1999. Globalisation as Reterritorialisation: The Re-scaling of Urban Governance in the European Union. Urban Studies 36(3): 431-451.

CASTRO, L. 2005. Regionalismo y desarrollo Regional: Debate público, proyectos económicos y actores locales (Tarapacá 1880-1930). Universidad de Valparaíso y Universidad Santo Tomás, Viña del Mar.

CAYO, P. 1982. La obra peruanista de Antonio Raimondi. Boletín del Instituto Riva Agüero 11: 9-19.

CONTRERAS, C. y M. CUETO. 2000. Historia del Perú Contemporáneo. Instituto de Estudios Peruanos, Lima.

CONTRERAS, C. y M. CUETO. 2008. Caminos, ciencia y Estado en el Perú, 1850-1930. História Ciência, Saúde - Manguinhos 15(3): 635-655. 
CONSTANZA, L. 2010. Editorial Colonización y consolidación del territorio en el siglo XIX: las nuevas naciones americanas. Apuntes. Revista de Estudios sobre Patrimonio Cultural 23(2): 102103.

CRAIB, R. B. 2000. Cartography and Power in the Conquest and Creation of New Spain. LatinAmerican Research Review 35(1): 7-36.

CRAIB, R. B. 2001. State Fixations, Fugitive Landscapes: Mapping, Surveying and the Spatial Creation of Modern Mexico, 1850-1930. Yale University Press, New Haven, CT.

CUETO, M. 1989. Excelencia científica en la periferia. Actividades científicas e investigación biomédica en el Perú 1890-1950. Grade-CONCYTEC, Lima.

D'AMICO, P. et al. 2013. Territorio y reproducción social: herramientas conceptuales para repensar el desierto de Lavalle (Argentina). Ambiente y Desarrollo 17(33): 57-70.

DELEUZE, G. 1990. ¿Qué es un dispositivo? En Michel Foucault, filósofo, E. Balbier et al., pp. 155-163. Gedisa, Buenos Aires.

DEMATTEIS, G. y F. GOVERNA. 2005. Territorio y territorialidad en el desarrollo local. La contribución del modelo Slot. Boletín de la Asociación de Geográfos Españoles 39: 31-58.

DONOSO, C. y J. ROSENBLITT (Eds.). 2011. Guerra, Región y Nación: La Confederación Perú-Boliviana 1836-1839. Universidad Andrés Bello y Centro de Investigaciones Diego Barros Arana (DIBAM), Santiago.

FIGUEROA, C. 2011. Cartografiando el progreso: espacios de civilización y barbarie en la provincia de Tarapacá, norte de Chile (1825-1884). Scripta Nova. Revista Electrónica de Geografía y Ciencias Sociales XV(379): s/p.

FLORES, C. 2000. El civilismo y la cuestión del salitre, 1872-1876. Historia. Revista de Historia y Sociedad 1(1): 39-47.

FISHER, J. 2000. El Perú borbónico 1750-1824. IEP, Lima.

FOUCAULT, M. 2002. Vigilar y Castigar. Nacimiento de la prisión. Siglo XXI, Buenos Aires.

FOUCAULT, M. 2008. Historia de la sexualidad 1. La voluntad del saber. Siglo XXI, Buenos Aires.

GONZÁLEZ, S. 2009. El norte grande de Chile: la definición histórica de sus límites, zonas y líneas de fronteras, y la importancia de las ciudades como geosímbolos fronterizos. Revista de Historia Socialy de las Mentalidades 2(13): 9-42.
GONZÁLEZ, S. 2011. Auge y crisis del nitrato chileno: la importancia de los viajeros, empresarios y científicos, 1830-1919. Tiempo Histórico 2: 159-178.

GONZÁLEZ, S. 2012. La resistencia de los tarapaqueños al monopolio salitrero peruano durante el gobierno de Manuel Pardo, desde el estanco a la expropiación (1872-1876). Chungara 44(1): 101-114.

GONZÁLEZ, S. 2013. Las políticas salitreras peruana y chilena. ¿Del monopolio estatal a la libertad económica? (1873-1884). Cuadernos de Historia 38: 39-77.

GUEVARA, J. de D. 1993. Historia de la Química en el Perú. CONCYTEC, Lima.

HARVEY, D. 1989. The condition of postmodernity. Blackwell, Oxford.

HIERNAUX-NICOLAS, D. 2004. Henri Lefebvre: del espacio absoluto al espacio diferencial. Veredas. Revista del Pensamiento Sociológico 8: 12-25.

HOBSBAWM, E. 2012. Naciones y nacionalismo desde 1870. Crítica, Buenos Aires.

LARRAÍN, H. 1975. Descripción de la provincia de Tarapacá por William Bollaert. Norte Grande I(3-4): 459-479.

LLANOS, L. 2010. El concepto de territorio y la investigación en las Ciencias Sociales. Agricultura, Sociedady Desarrollo 7(3): 207-220.

LOIS, C. 1999. La invención del desierto chaqueño. Una aproximación a las formas de apropiación simbólica de los territorios del Chaco en los tiempos de formación y consolidación del Estado-nación argentino. Scripta Nova 38: s/p.

LOIS, C. 2007. La Patagonia en el mapa de la Argentina moderna. Política y "deseo territorial" en la cartografía oficial argentina en la segunda mitad del siglo XIX. En Paisajes del progreso. La resignificación de la Patagonia Norte, 1880-1916, P. Navarro Floria (Ed.), pp. 107-134. Educo, Neuquén.

LÓPEZ, C. 2001. La exploración y ocupación del Acre (1850-1900). Revista de Indias 61(223): 573-590.

LÓPEZ, L. y B. RAMÍREZ. 2012. Pensar el espacio: región, paisaje, territorio y lugar en las Ciencias Sociales. En Explorando territorios: una visión desde las ciencias sociales, A. López y M. E. Reyes (Coords.), pp. 21-48. UAM-X, CSH, México D.F. 
LÓPEZ-OCÓN, L. 2001. La Sociedad Geográfica de Lima y la formación de una ciencia nacional en el Perú Republicano. Terra Brasilis (Nova Série) 3: 1-18.

LYNCH, J. 2004. La España del siglo XVIII. Crítica, Barcelona.

Mc EVOY, C. 1994. Un proyecto nacional en el siglo XIX. Manuel Pardo y su visión del Perú. Pontificia Universidad Católica del Perú, Lima.

Mc EVOY, C. 1997. La Utopía Republicana. Ideales y realidades en la formación de la cultura política peruana (1871-1919). Pontificia Universidad Católica del Perú, Lima.

Mc EVOY, C. 2013. Del proyecto civilista a la república ocupada: Antonio Raimondi y la recuperación y preservación del patrimonio material y cultural del Perú. En En pos de la República. Ensayos de historia política e intelectual, C. Mc Evoy, pp. 269-283. Centro de Estudios Bicentenario, Municipalidad Metropolitana de Lima, Asociación Educacional Antonio Raimondi, Lima.

MEDINA, E. 2006. Aportaciones para la epistemología de los estudios sobre fronteras internacionales. Estudios Fronterizos 7(13): 9-27.

MILLONES, L. 2005. La historia natural en las Memorias de José Eusebio de Llano Zapata. En José Eusebio Llano Zapata. Memorias histórico, físicas, crítico, apologéticas de la América meridional. R. Ramírez et al. (Eds.), pp. 75-92. IFEA, Fondo Editorial PUCP, Fondo Editorial UNMSM, Lima.

MORO, O. 2003. ¿Qué es un dispositivo? Empiria. Revista de Metodología de Ciencias Sociales 6:29-46.

MONTAÑEZ, G. y O. DELGADO. 1998. Espacio, territorio y región: conceptos básicos para un proyecto nacional. Cuadernos de Geografía 7(1-2): 120-135.

MÜCKE, U. 2010. Política y burguesía en el Perú. El Partido Civil antes de la Guerra con Chile. Instituto Francés de Estudios Andinos e Instituto de Estudios Peruanos, Lima.

NADAL, F. 1990. Los nacionalismos y la geografía. GEO Crítica $\operatorname{XII}(86): s / p$.

NADAL, F. y L. URTEAGA. 1990. Cartografía y Estado: los mapas topográficos nacionales y la estadística territorial en el siglo XIX. GEO Crítica XV(88): s/p.

NAVARRO FLORIA, P. 2002. El desierto y la cuestión del territorio en el discurso político argentino sobre la frontera sur. Revista Complutense de Historia de América 28: 139-168.
NOGUÉ I FONT, J. 1989. Espacio, lugar, región: hacia una nueva perspectiva geográfica regional. Boletín de la Asociación de Geógrafos Españoles 9: 49-62.

NÚÑEZ, E. 1987. Viajes y viajeros extranjeros en el Perú. CONCYTEC, Lima.

ORREGO, J. L. 2005. La ilusión del progreso. Los caminos hacia el Estado-nación en el Perú y América Latina. Pontificia Universidad Católica del Perú, Lima.

PANIAGUA, V. 2009. Manuel Pardo y el Partido Civil. Apogeo y crisis del primer partido político en el Perú. Fondo Editorial del Congreso del Perú, Lima.

PEASE, F. 1993. Perú, Hombre e Historia. La República, vol. III. Ediciones Edubanco, Lima.

PIETSCHMANN, H. 1996. Las reformas borbónicas y el sistema de intendencias en Nueva España. Un estudio político administrativo. FCE, México.

POOLE, D. 2000. Visión, raza y modernidad. Una economía visual del mundo andino de imágenes. Sur Casa de Estudios del Socialismo, Lima.

PRECEDO, A. 2004. Nuevas realidades territoriales para el siglo XXI. Desarrollo Local, Identidad Territorial y Ciudad Difusa. Síntesis, Madrid.

RAJCHENBERG, E. y C. HÉAU-LAMBERT. 2007. La frontera en la comunidad imaginada del siglo XIX. Frontera Norte 19(38): 3761.

RAJCHENBERG, E. y C. HÉAU-LAMBERT. 2008. Para una sociología histórica de los espacios periféricos de la nación en América Latina.Antípoda 7: 176-196.

RAIMONDI, A. 1874. El Perú, tomo I. Imprenta del Estado, Lima.

RAIMONDI, A. 2003. Informe y polémicas sobre el guano y el salitre (Perú 1854-1877). Fondo Editorial Universidad Nacional Mayor de San Marcos y Corporación Financiera del Desarrollo, Lima.

RODRÍGUEZ, D. 2010. Territorio y territorialidad. Nueva categoría de análisis y desarrollo didáctico de la Geografía. Uni-pluri/ versidad $10(3)$ : 1-11.

ROULLEAU-BERGER, L. 1999. Le travail en frinche (les modes de la petite production urbaine). Editions de l'Aube, Paris. 
RUIZ, J. P. 2011. Introducción. Mensuras, catastro y construcción estatal. En Mensurar la tierra, controlar el territorio. América Latina, siglos XVIII-XIX, C. Garavaglia y P. Gautreau (Eds.), pp. 13-25. Prohistoria ediciones, Buenos Aires.

SAGREDO, R. 2009. Del Chile imperial al Chile nacional. América meridional analizada por los naturalistas. En Ampliando miradas. Chile y su historia en un tiempo global, F. Purcell y A. Riquelme (Eds.), pp. 43-72. Instituto de Historia Pontificia Universidad Católica de Chile y RIL editores, Santiago.

SACK, R. (1986). Human Territoriality. Its Theory and History. Cambridge University Press, Cambridge.

SÁNCHEZ, J-E. 1991. Espacio, economía y sociedad. Siglo XXI, Barcelona.

SANTOS, M. (1994). O Retorno do Território. En Território: Globalização e Fragmentação, M. Santos, M. A. de Souza y M. L. Silveira (Coords.), pp. 15-20. Hucitec-ANPUR, São Paulo.

SANTOS, M. (1996). De la totalidad al lugar. Oikos-Tau, Barcelona.

SEINER, L. 2003. Antonio Raimondi y sus vinculaciones con la ciencia europea 1851-1890. Boletín del Instituto Francés de Estudios Andinos 32(3): 517-537.
STORPER, M. 1997. The Regional World. Territorial Development in a Global Economy. The Guilford Press, New York / London.

TUAN, Y-F. 2001. Space and Place: The Perspective of Experience. University of Minnesota Press, Minneapolis.

VANIER, M. 1999. La récomposition territoriale. Un 'grand débat' idéal. Espaces et Sociétés 96:125-143.

VILLACORTA, L. 2003. Antonio Raimondi, semblanza de un naturalista enciclopédico. En Antonio Raimondi. Informes y polémicas sobre el guano y el salitre (Perú: 1854-1877), L. Villacorta (Ed.), pp. 19-77. Fondo Editorial de la Universidad Nacional Mayor de San Marcos y Cooperación Financiera de Desarrollo, Lima.

VILLACORTA, L. (Comp.). 2006. Antonio Raimondi. Colección Estudios Geológicos y mineros para la Obra El Perú, vol. II: El departamento de Ancachs. Fondo Editorial de la Universidad Nacional Mayor de San Marcos, Lima.

WILLIAMSON, J. 1860. Observaciones sobre la industria de la provincia de Tarapacá. Tipografía de Mariano Gómez y Cía., Callao. 


\title{
ARCHIVO GENERAL DE LA NACIÓN DEL PERÚ, COLECCIÓN ANTONIO RAIMONDI, LIBRETA N ${ }^{\circ} 2$, PROVINCIA DE TARAPACÁ 1853
}

\author{
Lima 3 Noviembre 1853. \\ Entre San Gallian y la Bahía de la Independencia.
}

PÁG. 2

Salida de Lima por Iquique sobre el Vapor Bolivia el día 3 Noviembre 1853 a las 4 pomeridianas.

Llegada a Pisco sin novedades día 4 a las 11 antimeridianos.

Salida de Pisco a las 12 del día.

Entre San Gallian y La Bahía de la Independencia existen formaciones cristalinas cubiertas de rocas sedimentales. El día 5 a las $4^{1 / 2}$ pomeridianos pasamos delante la Quebrada de Chala. El día 6 a las $9^{1 / 2}$ pasamos delante [de] Camaná y la Quebrada de Chilca y a la una pomeridiano llegamos a Islay, ${ }^{35}$ paramos allí hasta

35 Islay es un pequeño puerto con un muelle recientemente fabricado y que ha costado 52000 pesos. Aunque este muelle presente mucho más comodidades que el antiguo, sin embargo es todavía difícil el desembarco de los pasajeros y de los bultos principalmente cuando la mar es un poco picada.

Este pueblo tiene un aspecto triste y árido por la falta de vegetación. Algunos años [atrás] faltaría también de agua, en el día [de hoy] tiene bastante comodidades por el agua habiéndose traído por medio de conductos que la suministran a dos pilas y además continua por medio de un conducto hasta el mismo muelle; de modo que al presente es muy fácil abastecer de agua a los buques. Islay es un puerto que, aunque incómodo, es bastantemente frecuentado por la razón que sirve para introducir todas las mercancías que van a Arequipa y Cuzco.

Este pueblo es fabricado sobre una formación granítica que en algunas partes pasa a una roca puramente feldespática. El feldespato, que forma la mayor parte de estas rocas, está sujeta a descomponerse y transformarse en caolín, de modo que todas las partes bajas que rodean Islay están cubiertas de este caolín pulvervulente mezclado con arena, y da un aspecto a todos los alrededores de Islay como si fuesen cubiertos de nieve. A una cerca de Islay se encuentra algunos olivares que recrean un poco la vista fatigada por la aridez de los alrededores de Islay. En ciertos lugares se encuentran muchas palomas (Columbia fremate, Columbia meloda,
PÁG. 3

las cuatro del mismo día y pues continuamos el viaje hasta Arica donde llegamos el día 7 a las 11 y media.

Arica pequeña ciudad situada a [espacio] es fabricada sobre un terreno de aluvión antiguo el mismo que cubre casi toda la costa del Perú.

El aspecto de esta pequeña ciudad es bastante agradable tanto mirada de la mar como en tierra. Tiene un muelle antiguo y ahora se está fabricando uno nuevo mucho más largo y que presente mayor facilidad para desembarcar, también se piensa fabricar de nuevo la aduana, por cuyo objeto se está rellenando una parte del mar, a donde el agua es muy baja, con gruesas piedras y tierras que se bajan de un cerro situado al sur de Arica. Este cerro conocido con el nombre de Morro de Arica domina la ciudad dándole un aspecto un poco triste elevándose perpendicularmente, así cerca del puerto, a una altura de [espacio], parece enterrar la ciudad a la menor sacudida de un temblor; por otra parte, pero sirve a los navegantes para conocer el puerto de Arica desde lejos. La formación de este cerro varía mucho.

\section{PÁG. 4}

Salida de Arica por Iquique sobre el vapor del Estado Apurímac el día 17 a las 5 de la tarde y llegada a Iquique el día 18 a las 2 pomeridianos. ${ }^{36}$

Columbia gracitis) y se oye el canto de muchos otros pajaritos como gorriones, zonotrichia matutina, piches (hummus militaris) y algunos picaflores (ornysmi amazifia y ornysimi cora).

36 Gobernador de Arica Saldívar, de Iquique Idelfonso Loaiza, de La Noria Don Manuel Romero Copa, de Pica Don Leandro Baltierrez. Comisario de Quillagua Diego Salazar, de Tamentica Inocencio, de Guatacondo Mariano Chávez, de la Tirana José Ribeira. 
Salida de Iquique para La Noria el 24 a las 2 de la tarde, apenas afuera del pueblo se entra en un arenal, en seguida empieza una costa bastantemente elevada, el camino que forma esta costa es formado por un terreno sedimental compuesto de arena y fragmentos de las rocas que rodean estos lugares, parece que en un tiempo haya sido una quebrada que se ha rellena

\section{PÁG. 5}

do, lo que vende posible la existencia del agua en la llanura donde está situado Iquique ligado a la sumidad de esta costa. Se ve luego casi en frente, un poco a [la] izquierda del camino, el cerro de Santa Rosa que se eleva más arriba de los otros que le están cerca. Continuando el camino por La Noria, que es bastantemente regular, se pasa en medio de formaciones feldespáticas que a veces [es] ferruginosa y piroxénicas. Las rocas feldespáticas en varios puntos están muy descompuestas y dan origen a una gran cantidad de caolín. Todos estos cerros tienen un aspecto volcánico.

Más allá empezamos a entrar en los terrenos salitrosos y después de 10 leguas de camino entramos en La Noria Nueva. Este pueblo, si queremos llamarlo así, le viene su nombre de una noria o máquina para elevar el agua que en otro tiempo allí existía y que al presente no se halla más. El punto que verdaderamente se llama La Noria no es [más] que la reunión de muy pocas oficinas de salitre, pero si comprendemos también todas las oficinas de salitre que se encuentran en sus alrededores, este lugar puede tener una población cerca de mil habitantes.

\section{PÁg. 6}

La excavación y purificación del nitrato de soda (salitre) constituye el trabajo de todos los habitantes de este lugar. Los terrenos que tienen el salitre se llaman allí calicheros, porque caliche se llama el salitre bruto. Este caliche se encuentra en una capa que varía de espesor en los diferentes lugares, teniendo pocas pulgadas en algunos puntos y hasta 4 varas en otros. Este caliche se encuentra ordinariamente en los terrenos un poco inclinados y casi siempre bajo una capa de arena llena de fragmentos de rocas ordinariamente feldespáticas cuyo espesor también varía, más que se puede considerar término medio de un pie. Bajo del caliche se encuentran todavía otras capas de tierras sueltas, también llenas de fragmentos de rocas y que en algunos puntos son muy cargadas de cristales de glan- berita (sulfato de soda y cal) y de pequeñas masas como en forma de papas de sorbato de cal, substancia descubierta recientemente. Esta materia*, como he dicho, se encuentra como en papas esparcidas sin orden en estos terrenos. La extracción del salitre se hace del siguiente modo. Antes se saca por medio de barretas el caliche de los terrenos que lo contienen; más si como a veces este caliche se presenta en capas de un cierto espesor, entonces no bastan las barretas, o al menos seria dema

\section{PÁG. 7}

siado larga la operación, y es preciso recurrir a la pólvora como se hace por los minerales metálicos. En este lugar se hacen los barrenos de un diámetro muy grande, se cargan con gran cantidad de pólvora (12 y 13 quintales) y se pega fuego.

Por este medio se despegan pedazos muy grandes [de] caliche, después por medio de masas de hierro se rompen en pequeños fragmentos aislándolos también de la materia terrosa que puede ser mezclada, y así se obtienen los caliches limpios y en pequeños pedazos que pasan a la segunda operación que es la purificación. Esta se hace en grandes fondos de hierro del diámetro de una vara a una y media dispuestos por pares. Cada par se llama una parada y tiene un hornillo común, situado en el medio, y dos chimeneas laterales. El combustible empleado para esta operación es el carbón de piedra que viene transportado de Iquique.

Se llenan antes los fondos con agua que se saca de pozos escavados allí. Sobre el lugar se pone el caliche en pequeños pedazos y se hace hervir. Todas las substancias solubles se disuelven, eso es el salitre y la sal; más si como la sal se disuelve casi en igual cantidad tanto en el agua fría como en la caliente, y al contrario el salitre se disuelve en mucha mayor proporción en el agua caliente que en la fría, de consiguiente resulta que se hace hervir por

\section{PÁG. 8}

mucho tiempo el líquido se concentra y casi toda la cantidad de sal no pudiendo más estar disuelta se precipita al fondo bajo la forma de pequeños cristales, mientras

\footnotetext{
* Esta materia es de un blanco de nieve, una estructura fibrosa de un aspecto sedoso muy suave al tacto, que se asemeja al amianto, de modo que algunos lo han confundido con este último.
} 
que el salitre queda en disolución. De este modo se separa casi la totalidad de la sal, después se dejan sentar las materias insolubles con la sal, en seguida se saca todo el líquido que tiene en disolución el salitre y se vacía en una tinaja que está situada delante de los fondos y que tiene la capacidad de los dos juntos; allí se dejan sentar un poco todas las materias que tiene en suspensión; entretanto se limpian con palos los fondos de todos los materiales insolubles y de la sal que se botan y se llenan los fondos otra vez.

El líquido sentado en la tinaja se saca por medio de un balde y de una gran cuchara de fierro y se vacía en bateas (recipientes de fierro rectangulares de dos varas de largo, una de ancho y una tercia de alto) que sirven para hacer cristalizar el salitre. El día siguiente se saca por medio de palas el salitre cristalizado y se amontona sobre el terreno para hacerlo secar. Con una parada se hacen dos o tres cocciones cada día que se llaman allí fundadas. Cada fundada produce 8 quintales de salitre, de modo que cuando se hacen tres fundadas cada día se produce con una sola parada 24 quintales diarios de salitre.

\section{PÁG. 9}

Para producir por este medio 20 quintales de salitre se consumen 4 quintales de carbón, el cual se podría economizar mucho si se hubiese a calentar los fondos por medio del vapor producido por una caldera y cuyo vapor se podría utilizar condensándolo para obtener agua dulce que falta en este lugar. Ahora recientemente se ha dada un privilegio exclusivo por la introducción de una máquina con la que se beneficia el salitre por medio del vapor, y no empleando el vapor solamente como medio calorífico sino que también como disolvente del salitre. La construcción de esta máquina es la siguiente. El vapor es producido por una caldera que comunica por medio de cuatro tubos con otros cuatro recipientes en forma de embudos y cerrados herméticamente, y que tiene algunos agujeros en su parte inferior. En estos recipientes se pone el caliche el que se carga abriendo la parte superior de estos recipientes; después se cierran y por medio de llaves se introduce el vapor que viene de la caldera, el cual pasando a través del caliche disuelve el salitre que cae en estado líquido pasando a través de los agujeros perforados, en la parte inferior de los recipientes, y se coge en otros que están situados debajo. El agua que sirve para estos trabajos se saca, como he dicho, de pozos practi- cados sobre el lugar mismo donde se beneficia el salitre, y cada parada tiene el suyo. Esta agua que se encuentra a una profundidad que va desde 2 a 8 a 10 varas, no es potable y tiene un sabor salitroso, de modo [ilegible]

\section{PÁG. 10}

pero las bestias la beben sin repugnancia. El agua que sirve por los usos de los habitantes del país viene transportada desde 3 leguas de distancia.

El pueblo de La Noria está situado en una parte muy baja y es fabricado en una pampa cubierta enteramente de sal, más lo que es enteramente extraño allí [es que la] sal forma tantas eminencias sobre el terreno como en forma de olas, y parece un mar que se haya solidificado, lo que viene muy difícil el caminar por esta pampa. En los alrededores, en los terrenos un poco inclinados, es donde se encuentran los calicheros que se explotan para barretizar el salitre; y más allá [de] este terreno está rodeado por todas partes de terrenos que manifiestan hasta la evidencia la formación volcánica, encontrándole por todas partes pedazos de rocas feldespáticas llenas de poros y concavidades que hacen conocer su origen ígneo. Muy cerca de La Noria se halla un pequeño cerro aislado de cerca 100 varas de altura, de una forma cónica y formada por una roca feldespática de la que se encuentran tanto sobre sus flancos como a la sumidad tantos pedazos que manifiestan haber existido en el estado sino líquido o a lo menos pastoso lo que no hace dudar, siendo aislado, su origen volcánico.

Un poco más allá hacia el NO se halla otro cerro que, a su configuración, parece un volcán extinguido observando toda vez a su sumidad en concavidad, en forma de cráter. (Ver Figura 1). Esta concavidad tiene una sola salida que parece ser la que ha dado pasaje a la materia fundida de la que se observa todavía

\section{PÁG. 11}

grandes masas sobre los flancos del cerro. Estas masas, que a veces son de un color gris obscuro, otras veces color de chocolate o amarilla, y que en algunas partes pasan al rojo por el peróxido de fierro que tienen, todas son de origen feldespáticas y manifiestan claramente haber sido fundidas por tener algunas una superficie llena de agujeros o concavidades, otras como en forma de olas por la consistencia pastosa que había tenido la 


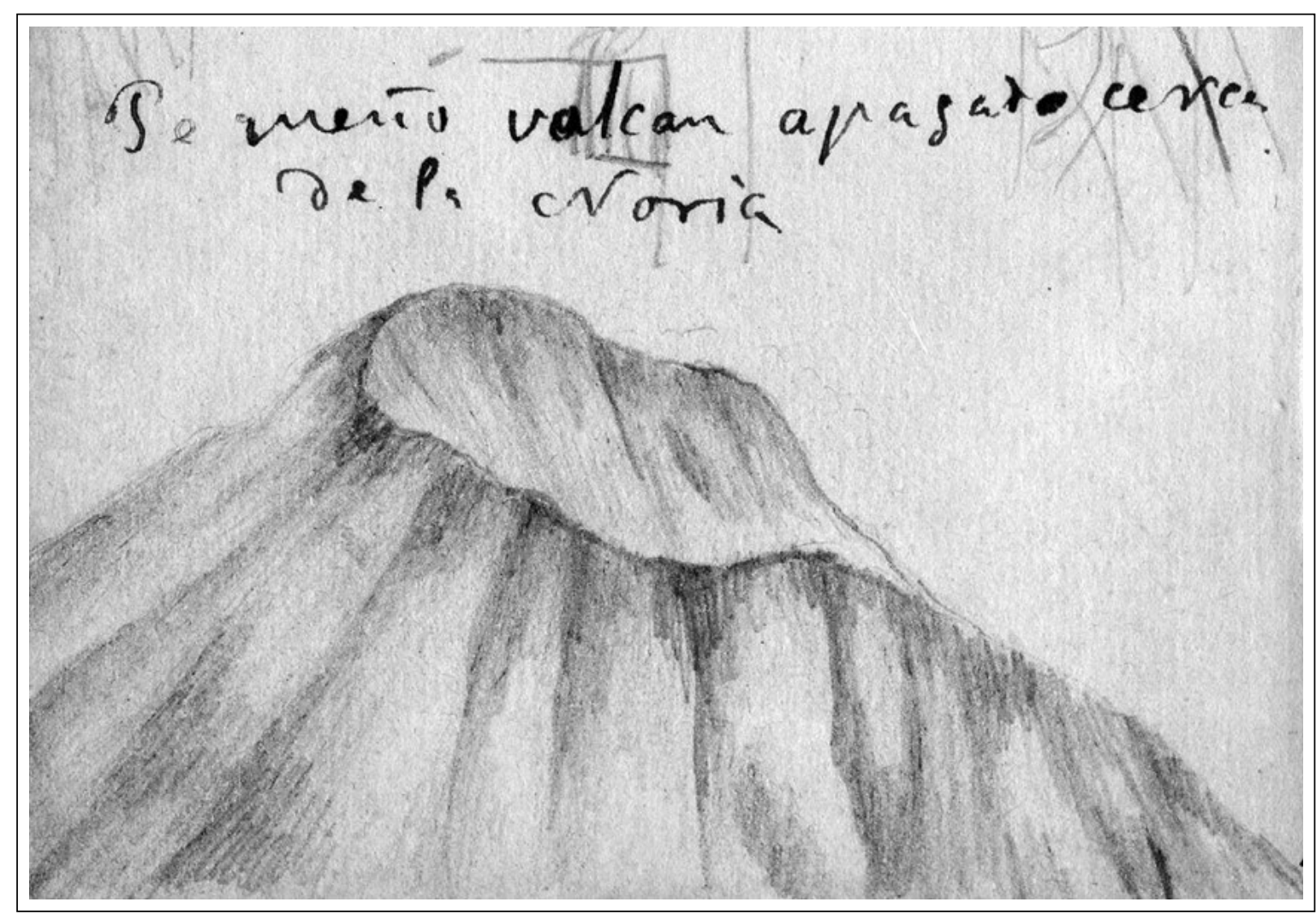

Figura 1. Volcán apagado cerca del pueblo de La Noria. A. Raimondi, Provincia de Tarapacá, 1853.

masa. Al presente casi toda la superficie del centro, y principalmente donde el llano o cóncavo está cubierta de concreciones de yeso mezclado con sal, parece haber sido cubierto por el agua, observándose en algunos puntos una capa de sal cubierta por una de arcilla de muy poco espesor. Entre las piedras feldespáticas que recogí sobre los flancos del cerro, hallé una tan cargada de óxido de fierro que se puede considerar como fierro oligisto, teniendo también en su interior el brillo de este último mineral. Todos estos terrenos están cubiertos de piedras sueltas de forma redondeadas, de diferente tamaño, que varía de aquel de una nuez al de una gruesa papa. Estas piedras de un blanco puro, que al exterior son bastantemente blandas

\section{PÁG. 12}

para poder reducirse a polvo solamente con los dedos, tiene en su interior un núcleo bastante duro que se deja rayar con dificultad por un instrumento de hierro. Por su forma redondeada y que parecen resultar como de la reunión de otras pequeñas masas que, con término mi- neralógico pueden llamarse apozonadas, manifiéstase claramente haber sido depositadas por el agua. Lo que prueba pues su origen sedimental es encontrarse todavía en algunos lugares en una capa que cubre el caliche y que en algunas partes están cubiertas ella misma por otra capa de arena, y en otras se manifiesta a la superficie formando como un empedrado.

El día 5 de Diciembre nos alistamos por el viaje en la Pampa del Tamarugal, y debiendo viajar por despoblados tomamos con nosotros un guía bien práctico del lugar, 4 peones para ayudarnos y un arriero para que cuidase las bestias. Nos proporcionaron también los víveres necesarios por un mes y una carpa para abrigarnos [en] la noche.

El 6 salimos a las 3 de la tarde de La Noria y a las 5 estábamos en la Rinconada. La Rinconada es un pequeño pueblo que ahora está deshabitado y sus casas ya no tienen techo. Este pueblo parece que haya sido fabricado solamente para beneficiar los metales 
PÁG. 13

de las célebres minas de Huantajaya y Santa Rosa y de cuyos trabajos se ven todavía avances. Estos metales se transportaban hasta la Rinconada porque en la cercanía de estos minerales no hay agua. Más desde que las minas de Santa Rosa y Huantajaya cesan de dar buenos minerales, estos trabajos paralizaron y el pueblo de la Rinconada fue abandonado y cayó en ruinas. En el día se ve todavía los restos de una pequeña Capilla y de algunas casas. Los pozos que en aquel tiempo daban el agua necesaria por el beneficio de los metales al presente son enterrados. En el día existe un solo pozo que da muy poca agua y es situado algunas cuadras antes de llegar al pueblo, en una especie de corral llamado Cosallón de la Rinconada. El agua se halla a la profundidad de cavar 4 varas y es mucho mejor que la de La Noria, aunque sean un poco salobre. Alrededor de este pueblo se hallan algunos árboles de tamarugo, lo que le quita aquel aspecto triste y árido que se nota en muchas partes de esta gran pampa. Apenas entrado en la pampa se encuentran algunos caliches de sal no tan irregulares como los que he notado en La Noria. Debajo de este caliche, por todas partes se encuentran trozos de borato de cal pero en pequeña cantidad que no sería suficiente para pagar los gastos para sacarlo.

\section{PÁG. 14}

Más adelante, cerca del pozo, empieza una cinta de terreno llano donde no se encuentra el caliche de sal y que parece que haya pasado agua por este lugar. Esta especie de río seco se dirige de Nor a Sud y tiene en casi toda su longitud una capa de borato de cal casi de un tercio de espesor y casi superficial. Cerca de la cercanía que forma el lado derecho, entrando en la pampa, también existe otra lengua de tierra que tiene mucho borato. En esta parte se encuentra el borato de cal en abundancia, también debajo del caliche de sal, y es a notar que el borato de cal existe casi siempre en mayor abundancia donde se encuentra una capa de tierra que presenta un cierto grado de humedad. El 8 a las 2 de la tarde desarmamos el toldo, envolvimos todas nuestras cosas y las 2 de la tarde nos pusimos en marcha por Challapozo, haciendo excavaciones de cuando en cuando en el camino, encontrando en ciertos puntos bórax y en otros apenas los rastros. Llegamos a una aguada que dista casi dos leguas de la Rinconada y donde el agua se encuentra a profundidad de cavar dos varas. El agua además de ser salada tiene un sabor muy malo debido a muchas
PÁG. 15

substancias que caen adentro y se pudren. Llegamos a Challapozo como a las 6 y allí plantamos nuestro campamento. Challapozo consiste en una sola casita habitada y en alguna otra destruida [que], al presente, es la mansión de nuestro guía que habita allí cortando leña de algunos tamarugos que existen en aquellas serranías, y transportando a La Noria que la emplean como combustible para beneficiar el salitre. El agua de Challapozo es todavía mejor que la de la Rinconada, es apenas un poquito salobre; se encuentra en este lugar a la profundidad de cerca 3 a 4 varas. En las cercanías se Challapozo no existen estos grandes calichales de sal que se notan en los puntos ya citados, aquí más bien es un terreno suelto cubierto en algunas partes de grama y de algunos tamarugos que en gran cantidad existían en otro tiempo, más que en el día han disminuido mucho por el corte que hacen o para hacer carbón o para transportarlos como leña a las oficinas del salitre.

\section{El día 9 salimos de madrugada por el camino}

PÁG. 16

de la Cabrería, examinando en diversos punto el terreno para reconocer si tenían borato de cal el cual encontramos en muchos puntos; más los que nos extrañó mucho fue encontrarlo en algunas partes bajo una forma y consistencia de manteca irreconocible.

En los gramadales inmensos que se hallan por aquellas partes, cuando se excava el terreno se encuentra con muchos puntos, a la profundidad de $1 / 2$ pies a $1 \frac{1}{2}$, una capa de cerca de dos de espesor de borato de cal de un color a veces café, blanco, otras veces amarillento de la densidad de una manteca que se aplana cuando se hace una bola y se pone sobre un lugar plano.

En ciertas partes se halla esta misma substancia que tiene mayor consistencia y que empieza a tomar su estructura fibrosa que le es propicia al borato de cal puro y sólido. Esta especie de borato de cal se halla principalmente cerca de la Aguada de Reyes, a una legua de Challapozo en el camino de la Cabrería. La Aguada de Reyes que hemos estado, ahora tiene un agua muy salobre y se halla a la profundidad de $1 \frac{1}{2}$ a 2 varas. Los hombres la beben en los casos 


\section{PÁG. 17}

de gran necesidad; y sirve solamente para dar de beber a los animales.

En todas estas partes no se puede salir con la bestia de la pequeña senda trazada por el pasaje de los animales a riesgo de hundirse a cada paso, porque donde no hay calichal duro se encuentran tantas excavaciones subterráneas hechas hasta bastante profundidades por pequeños animales del orden de los roedores llamado en el país Sartaneca, ${ }^{37}$ y que vive de las raíces de la grama y de otra planta llamada allí sorona, de la cual roe la raíz y hace secar la planta. También en los alrededores de Challapozo se encuentra mucho borato de cal, más de la variedad pastosa que ya hemos citado. No se puede, pero nunca, determinar la extensión de esta capa porque varía mucho encontrándose como en manchas, principalmente en los calichales de sal muy delgados donde hay grama.

El 10 salimos de Challapozo para la Quebrada de la Cabrería. Visitamos en el camino algunos calichales donde encontramos borato de cal en bolas y en los lugares más húmedos, donde hay grama, hallamos borato en masa. Paramos un poquito en la pascana de Don

\section{PÁG. 18}

Pedro Castro y continuamos el camino hacia la quebrada visitando a derecha y a izquierda, encontrando en algunos puntos borato y en otros no.

Antes de llegar a dicha quebrada amarramos las bestias a la sombra de un tamarugo y continuamos a pies haciendo muchas excavaciones y encontramos bórax en la mayor parte. Mas la mayor cantidad de bórax la hallamos más allá de una pequeña costa pedregosa, siempre continuando el camino hacia la quebrada. En este punto se halla hasta en dos capas sobrepuestas una a otra y separadas por una pequeña capa de tierra con sal. Volviendo paramos de nuevo en la pascana de Don Pedro Castro, que es una pequeña choza plantada bajo de un tamarugo y es muy cerca del agua y nos dirigimos un poco a la derecha, a 100 pasos de Reyes.

37 Ctenomys robustus, roedor altamente especializado para la vida subterránea, conocido actualmente como Sartaneja o Tucu-Tucu.
De dicha pascana se encuentra una capa de bórax a un pie de profundidad que tiene el aspecto casi de hueso o de cuerno.

En todos estos alrededores se hallan calichales que por la mayor parte manifiestan a la superficie escreciencias [sic] de formas redondeadas, formadas de una mezcla de borato de cal y cloruro de sodio.

PÁG. 19

El día 11 salimos de Challapozo con dirección al Tronco, no pasamos por el camino derecho más sino pasando por Challapocito.

Challapocito es formado por una sola casita y un pozo donde se halla agua a la profundidad de 2 varas, más es un poco salobre. Este lugar es lejos de Challapozo, cerca [de] una legua, y en sus alrededores encontramos en la mayor parte de las excavaciones borato en masa y un poco en bolas. Un poquito más adelante se encuentra la Aguada de Don Eduardo Santos en la que se halla el agua a muy poca profundidad, casi a la superficie. Cerca de esta aguada, siendo el terreno muy húmedo por la poca profundidad del terreno, se ha sembrado un poco de trigo. También en estos terrenos se halla bórax, encontrándose en masa bajo los gramadales y en bola bajo los calichales.

Continuamos después el camino a través de los calichales, de superficie tan escabrosa y toda erizada de puntos, que las bestias no podían andar todos estos calichales. Son de sal casi pura y blanca como la nieve y también se halla un poco de borato bajo de ello, indicando los

PÁG. 20

agujeros hechos por las sartanecas que a su entrada se ven pequeños trozos de bórax. Llegamos al Tronco donde paramos un poco. La pascana del Tronco consiste en un pequeño grupo de tamarugos, y una aguada a poca distancia que tiene el agua a una vara de profundidad y es muy salobre que no se puede tomar.

En todos los alrededores se encuentra al pie de la grama gran cantidad de bórax en masa y también bajo del agua calichal se halla lo de bolas. Continuamos después el camino hacia la Quebrada de Chanavaya, atravesando algunos gramadales y calichales llegamos a otra aguada 
que tiene agua regular, pasando [por] terrenos donde se halla poco borato de cal.

Llegamos como a las 4 de la tarde a la Aguada de Chanavaya. Esta aguada tiene agua en mucha abundancia y muy regular a la profundidad de cerca dos varas, y es situada un poco a la izquierda del camino que viene de La Noria Nueva. Cerca de esta aguada encontré por la primera vez algunas conchas marinas en una tierra suelta; estas conchas pertenecen al género Patella y Fissurella. (Ver Figura 2).

En los alrededores de esta aguada se halla alguna capa de yeso que algunos parece se hayan confundido con el borato de cal a pesar de que se encuentra en muy pequeña cantidad también este último.

El día 12 salimos de Challapozo con dirección a la Aguada de Santa Ana. Después de dos leguas de un camino muy regular llegamos a un bosque de tamarugos llamado
PÁG. 21

Monte Grande. Es muy delicioso el pasar a la sombra de estos árboles muy verdes después de tanta aridez, más una lástima muy grande es que entre poco tiempo también éstos casi desaparecerán por dar luego a un desierto; porque los van cortando para hacer leña y transportarla a las oficinas del salitre. Un 1/4 de legua más adelante se encuentra la de Lucas Palape, donde se halla una aguada que tiene agua muy regular a la profundidad de tres varas en un terreno compuesto de capas alternada de arena y arcilla. Otro $1 / 4$ de legua más adelante se encuentra la Aguada de Santa Ana, la que consiste en dos pozos grandes del diámetro de cerca tres varas. Estos pozos, que distan uno de otro cerca de dos varas, tienen el agua a la profundidad que forma una capa de una vara de espesor. Parece que en otro tiempo se cultivaban los terrenos que están en sus alrededores, porque todavía al presente se ven parte de estos terrenos dispuestos en esas como por el sombrío.

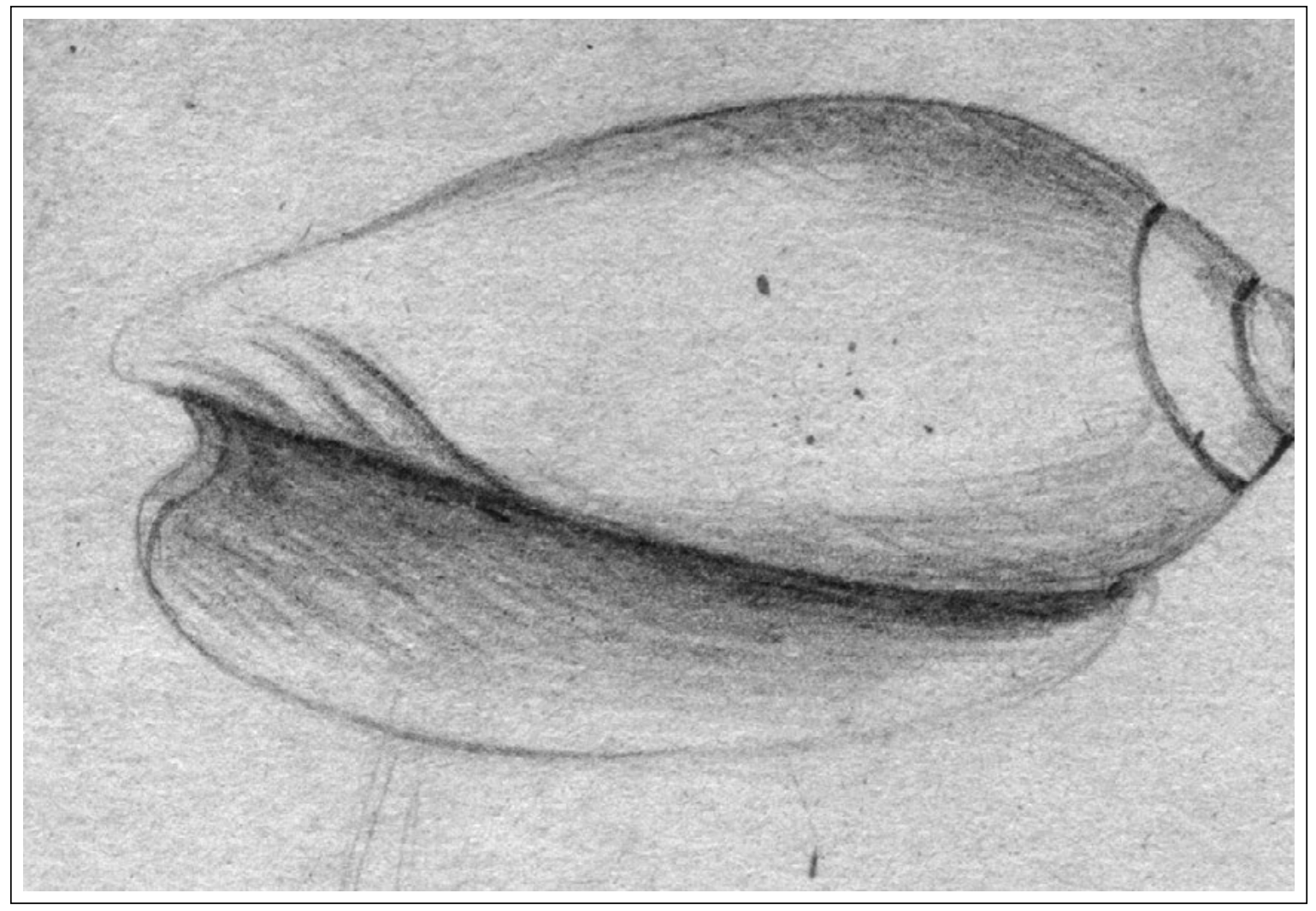

Figura 2. Concha marina encontrada en la Aguada de Chanavaya. A. Raimondi, Provincia de Tarapacá, 1853. 
A 3/4 de leguas de distancia se halla la Aguada de Hidalgo la que tiene el agua a vara y media de profundidad, más que al presente es podrida por muchas substancias orgánicas que le han caído dentro. A pocos pasos existe un gran tamarugo que a su base tiene dos varas y 10 pulgadas de diámetro, a poca distancia de esta aguada se halla otra que tiene agua buena. En todos estos terrenos se halla borato en masa pero en poca cantidad. A media legua de distancia se halla la Aguada de San Francisco que tiene agua buena a media vara de profundidad.

Después continuamos el camino hacia La Noria pasando por muchos calichales, donde [fuimos] haciendo excavaciones para ver si había borato, encontra

\section{PÁG. 22}

mos en varios puntos un poco de éste en masa y una pequeña cantidad en bolas, más lo que extraña mucho es ver la cantidad de troncos de tamarugo que se encuentran enterrados, lo que hace suponer hayan sido estos lugares en otro tiempo un monte muy espeso. Ahora sirven estos troncos a los señores que hacen este comercio transportándolos a las oficinas de salitre, principalmente a La Noria Nueva, adonde lo pagan de 15 a 17 pesos cada 100 arrobas. Esta madera es muy pesada de modo que un pequeño bulto que cargamos [en un] burro pesa 8 arrobas.

Adelantando en el camino hacia La Noria se empieza a ver un poquito más de vegetación alternando con la grama y los tamarugos, algunas matas de vetama y de sorona..$^{38}$ En estos lugares se ha aprovechado de la humedad del terreno para sembrar y cultivar sin riego, y después de muchos trabajos un cierto señor, Don Mariano Morales y Núñez, ha llegado a obtener buenas cosechas de melones, sandías, zapallos, trigo, cebada, alfalfa, más una plaga muy grande a venido a disturbar su cultivo y es la aparición de una cantidad de gusanos que se comen toda la alfalfa y es tardío una buena suerte que estos gusanos no pueden resistir a los grandes calores y que cerca del fin de diciembre se mueven todos, de otra manera, de otro modo, se habría debido dejar estos terrenos tan fértiles.

Para cultivar estos terrenos no hay necesidad de levantar el caliche de sal que los cubre, y no es pues enteramente inútil

38 Tessaria absinthiodes, también llamada brea. este caliche porque sirve como material de construcción para fabricar casas cercas de los lugares cultivados.

Parece que también la cepa puede producirse, porque el citado señor tenía una que en este culti

\section{PÁG. 23}

vado año ha dado una y muy buena. Sería una muy buena cosa el estimular a este hombre que ha pasado tantos trabajos y sacrificios en los primeros años y porque ha dado un ejemplo a los de la provincia al hacer producir un terreno que antes era enteramente estéril. Quiera Dios que los otros sigan su ejemplo cultivando estos terrenos que venderá a muy rica esta provincia y no se vean obligados a emigrar como los que trabajaron minas siendo la agricultura permanente y no temporaria como las minas del salitre y el borato.

De allí volvimos a Challapozo pasando por Chayas, donde existe otra chacra formada por el ejemplo de la que hemos citado. Solamente que en esta su dueño, Don Bernardo Digoy, teniendo más capitales ha podido [emprenderla] más en grande, más también aquí como en toda la provincia se hallan en este año los gusanos que hemos citado que comen todo los alfalfares y muchas verduras que en esta chacra se han cultivado, solamente las gramíneas resisten a esta plaga.

En todos estos terrenos existe muy poca cantidad de borato en masa y en bolas.

El 13 lo empleamos en fijar varios puntos por medio de los instrumentos y el 14 levantamos nuestro acampamento para ir a ponerlo al Pozo de Quinto. A una legua y media de Challapozo encontramos un sartanecal, y en medio de la tierra separada por los animales hallamos algunos pedacitos de una sal blanca de un sabor particular, un poco más adelante encontramos calichales de

\section{PÁG. 24}

sal exfloreciente de un sabor poco disperso de la primera. A una legua y media antes de llegar al Pozo de Quinto se halla la Aguada de San Mauricio que tiene el agua regular a 4 varas y media de profundidad, más que al presente es un poco salobre por la tierra con sal que le cae adentro. Después, dejando un poco a [la] izquierda el Pozo de Obregón llegamos a la Aguada de Cabien que tiene 
el agua a cerca de tres varas y media de profundidad, y después de 6 leguas de camino desde Challapozo llegamos al Pozo de Quinto situado un poco más al Sud de Pintados. ${ }^{39}$ Esta pascana está formada por una casita y dos pozos, uno de los cuales llamado de Quinto del nombre de quien lo hizo. Este Quinto con otros compañeros eran reclutas que se escapaban de Pica escondiéndose en la pampa para no ser militar, y si como en este lugar no había agua escavaron este pozo que tiene más de doce varas de profundidad; mas siendo muy angosto y no suministrando agua bastante para todos los animales que en el día concurren a este pozo, el año pasado se escavó otro a pocos pasos de distancia que tiene doce varas de profundidad. El terreno en que esta escavado el pozo es formado en su mayor parte por una grande capa de arcilla de color rosado muy fina, que tiene esta agua siempre turbia teniendo en suspensión una gran cantidad, siendo este pozo más

\section{PÁG. 25}

concurrido que no tiene el tiempo de sentarse. En el día se hallan en los alrededores muchas chozas en la que viven varios leñadores. Todos los terrenos que rodean este pozo son muy uniformes encontrándose calichales de sal interrumpidas por cavausales, o sea terrenos cubiertos de arcilla abiertos en varios puntos por la sequedad. Todo el camino que conduce del Pozo de Quinto a Pica es formado por estos terrenos y algún arenal ${ }^{*}$.

El día 15 lo empleamos en registrar todos los alrededores del pozo y el 16 levantamos la carpa y nos trasladamos al Sur.

El camino del Pozo de Quinto al sur es trazado antes en un cavausal que contiene casi por más de dos leguas y pues se entra en los calichales y así continúa hasta las

39 Esto se continua [superficie calichal formada por una mezcla de bórax y cloruro de sodio] casi hasta Challapocito, allí torciendo a la derecha se entra en calichales de pura sal los cuales son inmensos y después torciendo de nuevo a la derecha se viene a Pintados, nombre dado a algunos cerros en los que se ven grabados por los antiguos, 117 figuras.

* En los alrededores del pozo hacia la parte de Pica encontré muchos cantos rodados algunos de los cuales eran formados de Traquita que parecen haber sido arrastrados por el agua desde la serranía. En esta parte de la pampa el borato de cal es muy escaso aunque siempre se encuentra cal rastrojo. oficinas del sur, siendo solamente interrumpido por algunas cuevecitas. Las oficinas de Los Linches, que pertenecían antes a Don Juan Williamson, son situadas como en una ensenada. Los calichales, como las de La Noria y del Salar, son situados siempre en los lugares inclinados. El agua que se halla en las oficinas es muy mala y se halla casi en la superficie que no se puede tomar y son obligados de traerla desde dos leguas

\section{PÁg. 26}

de distancia. En camino que conduce de las oficinas a la aguada es muy bueno y es construido a través de los calichales de sal que se han levantado para hacer una especie de cerco al camino mismo. A distancia de las oficinas, menos de una legua, debajo de los calichales, se encuentra bastante cantidad de borato en bolas que en algunos puntos tiene hasta dos pies de profundidad. Más adelante para ir a la aguada empiezan los gramadales, los que son formados por pequeños promontorios, todos de tiza en masa que secando se reduce con mucha facilidad en polvo y por eso allá le llaman tiza en harina. En fin, a dos leguas de distancia de la oficina se halla la aguada la que es muy grande y tiene el agua a una vara cerca de profundidad y agua regular como la de la Rinconada.

Cerca del aguada es donde se halla la mayor cantidad de tiza en masa que haya visto y por todas partes se puede sacar con facilidad porque no hay necesidad de levantar ninguna costra o calichal siendo a la vista. La aguada que he nombrado se llama Aguada Nueva para distinguirla de otra aguada de la que servían antes que se llama la Vieja. Cerca de la Aguada Nueva se han construido muchos corrales muy grandes que se sirven por las mulas que transportan el salitre de las oficinas a Patillo, puerto nuevamente habilitado para embarcar el salitre que se beneficia en el sur donde ya se ha construido alguna casa, más falta de agua como Iquique.

El día 17 salimos de la Aguada Nueva para ir a la Vieja que

\section{PÁG. 27}

está cerca de una legua. El camino es casi todo a través de calichales de sal donde no se encuentra caja de borato, más al contrario bajo de estos calichales se halla una caja de yeso que tiene muy poca cohesión y que se puede reducirlo por medio de los dedos a un polvo cristalino, siendo formado por la agregación de cristales muy pequeños. El 
agua en esta aguada no sale a la superficie sino a $4^{1 / 2}$ a 5 varas de profundidad y es mucho porque a poca distancia se ve como tantos pilares sobre los cuales se quería hacer pasar un tubo que habióse a conducir el agua del aguada hasta las oficinas, pero al presente esta obra está abandonada.

El día 18 pasamos al Monte de la Soledad a 14 leguas de distancia.

Después de una legua y media de camino se encuentra un pozo que tiene el agua a 4 o 5 varas de profundidad y sirve para abastecer el agua potable a las oficinas del Sur Vieja, apenas pasados este pozo atravesamos una lomada formada de rocas feldespáticas de origen volcánico, manifestando a su superficie indicios de fusión. Subido estos cerros, que son ramas de la cadena principal que se dirige de Nor a Sur cerca de la costa, bajamos insensiblemente hasta las oficinas del Sur Vieja que distan como 5 leguas de las otras oficinas del Sur que hemos citado. Al presente el trabajo está parado en estas oficinas y solamente se ven los restos de las casas y de un pozo que tiene el agua a 12014 varas

\section{PÁG. 28}

de profundidad y esta agua tiene otro tanto de espesor, porque cuando se excavó este pozo se halló agua cerca de doce varas mas no en cantidad suficiente para los trabajos y por esto se excavó otras doce o catorce varas y entonces subió el agua hasta quedar a la profundidad de cerca doce varas. El agua es muy mala y no se puede tomar, siendo como una purga y por eso se traía el agua potable hasta del pozo citado. Pasado las oficinas del Sur Vieja el camino sigue a través de una serie de pequeñas lomitas. A dos leguas del SurVieja se halla una pequeña laguna que va secándose poco a poco formándose costras de sal en su superficie, y da una idea de lo que habrán sido todos los calichales de la pampa en otro tiempo. Pasada esta laguna el camino continúa por planicies interrumpidas de cuando en cuando por pequeñas subidas y bajadas hasta la bajada llamada del Sur y que entra de nuevo en la pampa. Todos estos terrenos están cubiertos por las mismas piedras redondeadas y formadas por concreción que ya hemos notado en La Noria y en el salar. En esta parte son mucho más abundantes y se encuentran todavía en grandes capas formando como un empedrado sobre la mayor parte de este terreno. La bajada llamada del Sur es trazada toda en una gran formación de yeso, más este terreno es tan irregular que pasa como todo revuelto siendo todo lleno de concavidades, de eminencia, de pequeñas quebraditas por donde

\section{PÁG. 29}

pasa una senda trazada por las bestias y que sirve de camino.

Bajando a la pampa empiezan terrenos arcillosos y al pie de la bajada se halla un pozo escavado todo en la arcilla hasta 4 varas y media y no tiene agua.

Después de cerca dos leguas de camino en la pampa, a través un terreno arcilloso, se entra de nuevo en los calichales y luego se llega a los Puquios de los Quillagas [que] tienen el agua regular a media vara de profundidad.

Pasamos allí la noche y la mañana del 19 levantamos el campo para trasladarnos a Calate. Antes caminamos en el Monte de la Soledad que está un poco al norte de los Puquios de los Quillagas, más en todos estos terrenos encontramos apenas los rastros del Borato de Cal.

Nos dirigimos después de dos horas de vueltas en este monte hacia el camino de Huatacondo y llegamos a los puquios llamados de los Huantacondos donde se halla agua a la misma profundidad que en aquellos de los Quillagas y es solamente un poco más salada. Estos puquios están a una legua de distancia de los otros. Después se camina un poco al medio de los calichales de sal. Se entra después en una pampa para subir luego una pequeña cadena toda interrumpida de quebradas y profundidades. Todas estas series de cerros y la pampa no son que una gran formación de yeso como lo que forma la Bajada del Sur. En la pampa y cerca de los Puquios de los Quillagas se ven dos pequeñas excavaciones con el objeto de hallar tiza, y al contrario no

\section{PÁG. 30}

halla que yeso de una estructura cristalina. Pasada la formación de yeso se entra en terrenos cristalinos que varían a cada paso, pasando a veces a formaciones volcánicas. Todas las concavidades son rellenadas de calichales de sal, también en las partes altas.

Después de 6 a 7 leguas de camino desde los Puquios de los Huatacondos, a través [de una] formación así vavia- 


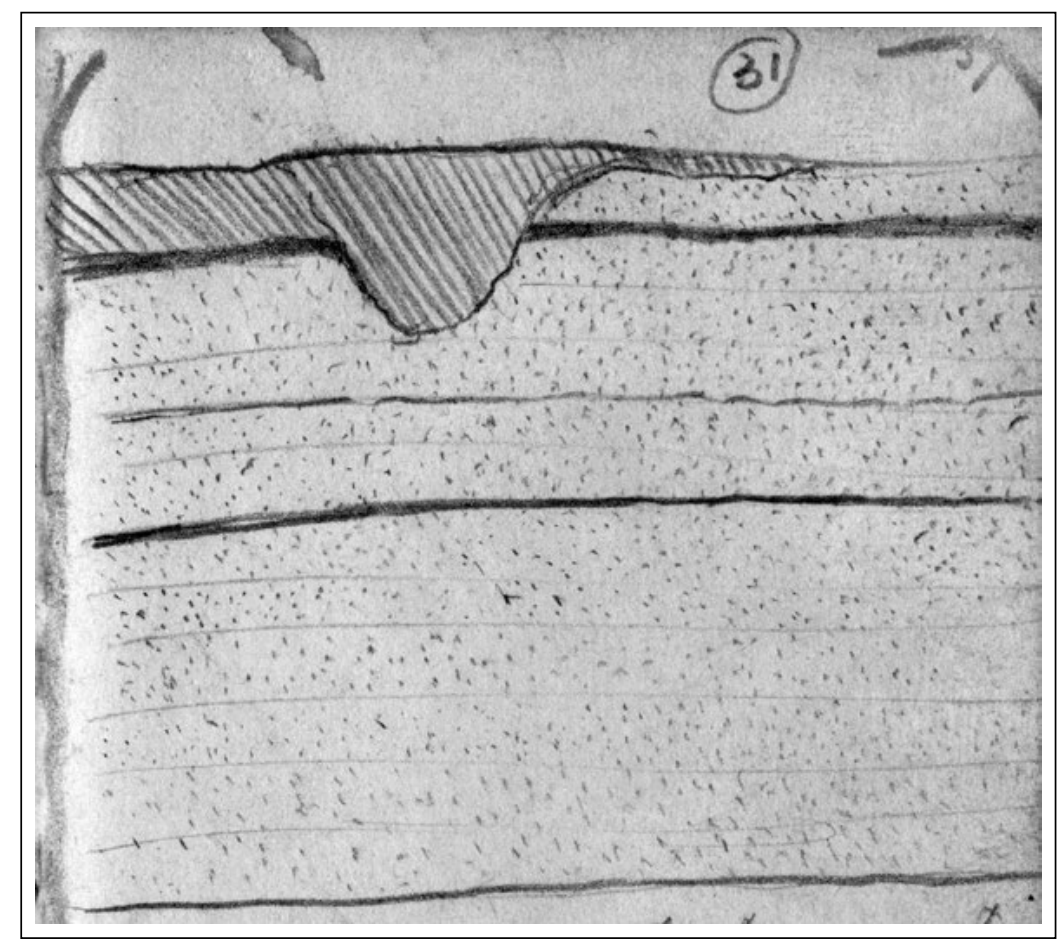

Figura 3. Perfil geológico del valle del río Loa cerca de Calate. A. Raimondi, Provincia de Tarapacá, 1853.

dades (sic) se entra de nuevo en una formación de yeso para bajar a la pampa. Esta formación en ciertos puntos cubre otra de pizarra. Llegado a la pampa se camina sobre arenales o sobre yeso hasta la Quebrada de Quillagua a donde se baja a Calate situado a la orilla del río Loa. Este río que tiene su origen en Bolivia y después de un corto camino muy tortuoso forma el confín entre Bolivia y el Perú, y desemboca en la mar entre Iquique y Cobija pasando por un pequeño pueblo situado a su desembocadura y que tiene el mismo nombre del río.

Calate no es un pueblo más solamente una pascana por los que van a Cobija u otras partes. Su situación es a la orilla del río Loa en una quebrada de más de 100 varas de profundidad, por la tarde reina un viento tan fuerte que precisa hacer fuerza para estar parado. La bajada a esta pascana es muy angosta, y en algunos puntos es peligrosa, siendo resbaladiza por eso es fácil caerse hasta el río. El camino es trazado sobre formaciones de yeso, de arcilla o de arena. En ciertos puntos de la quebrada estos terrenos están cortados perpendicularmente de modo que se puede estudiar bien las sucesivas formaciones teniendo
PÁG. 31

allí un corte de la pampa de más de cien varas de espesor.

La formación más inferior, y es la que tiene más espesor porque en algunos puntos la entera altura de la quebrada es formada por capas de arena mezcladas de pedazos de rocas diferentes. Estas capas de arena son interrumpidas por pequeñas capas de arcilla. Esta formación es cubierta en otros puntos por una capa de arcilla y finalmente por una de yeso cristalizado o selenita. Este yeso que se halla en cristalizaciones variadas, como en hierro de lanza en tablas romboidales, se tiene entre los intersticios dejados por los cristales pedacitos de rocas de arena. Se podrá hacerse una idea más clara de estas formaciones por la figura siguiente. (Ver Figura 3).

Parece, pero en otro tiempo, que esta quebrada se hallaba rellenada hasta una cierta altura de arcillas, porque de la otra banda del río se nota todavía una planicie un poco elevada formada toda de arcilla y parece haber sido arrastrada por el rio en hacerse paso a través [de] este terreno.

En esta parte del río que pertenece 


\section{PÁG. 32}

a Bolivia se hallan un poco más alto de la planicie de arcilla algunas formaciones de pizarra; sobre ésta se montan tantos cantos rodados como se haya pasado un río y en varios puntos un poco cóncavos se encuentra calichales de sal.

El agua del río Loa es un poco salada pero se puede tomar y es mejor si se toma un poco más arriba de Calate porque cerca de este punto entra otro pequeño ramo que viene de la Quebrada de Guanguac cuya agua es muy salada.

A las orillas de este río se halla un poco de vegetación, la que consiste en grama, una yuncaginea, una compuesta llamada muto-muto, otra compuesta llamada chilea.

La cantidad de agua de este río se puede avaluar a un canal que tenga dos varas de ancho de profundidad y la velocidad de 3 millas por hora.

Pasamos la noche en Calate y la mañana del 20 nos marchamos hacia Quillagua.

El camino por Quillagua se puede hacer tanto de la banda del Perú como la de Bolivia, nosotros hicimos aquel de la banda de Perú.

Este camino que se aleja muy poco del río es trazado sobre formaciones de yeso que por todas partes está cubierto de cristales lo que hace un efecto bonito de ver elevándose los rayos solares sobre todas estas superficies lucientes. En algunas partes este yeso cubre formaciones de pizarra. Más adelante también se notan formaciones volcánicas que en algún punto encierran el rio dejándole un pequeño pasaje. Después de 4 leguas de camino se pasa sobre terrenos cristalinos

\section{PÁG. 33}

que son por la mayor parte sienita a dos leguas de 2 millas que bajamos y entramos en la quebrada del río y pasando sobre terrenos arcillosos llegamos a Quillagua. Quillagua es un pequeño pueblo situado sobre la orilla del río Loa. Este lugar tiene una vista mucho más agradable que todos los demás puntos que hemos citado después de haber entrado en la gran pampa. Este aspecto agradable es debido a su vegetación la que es formada en su mayor parte por algarrobos indígenas y por muchas otras plantas cultiva- das como el maíz, la alfalfa, la quinuace. Entre las plantas que allí crecen espontáneamente se puede notar la cipapayo (especie de haveria), la chilca (molina), el muto-muto o puncho, la pillaya ${ }^{40}$ y la sororia que comen los animales, la chañara que da una pequeña drupa llamada pucura una especie de cuscuta, la grama, una yuncaginea. Además se halla algún tamarugo o algarrobillo.

Sobre estas plantas viven también muchas aves tales como gorriones llamadas ahí (pichincho), piches (chata), chirillo, muchas palomas y algunos patos en el río.

Entre los insectos que se notan en este lugar, además de moscones avispas, alguna especie de libélula, notaremos principalmente un insecto llamado chirimacha y que infesta todas las casas habitando en el terreno o en el techo y que entra de noche en las

\section{PÁG. 34}

camas molestando más que las pulgas y los chinches. Este insecto es del tamaño casi de una cucaracha. En este país aunque no sea tan adelantada la agricultura porque se desperdicia mucha agua, sin embargo se han hecho algunos trabajos de irrigación bajando del rio a media legua de distancia del pueblo dos acequias, una a derecha y otra a izquierda, para regar algunos terrenos que no habrían producido nada para ser demasiados altos. Hace poco tiempo que se ha emprendido otro trabajo del mismo género pero mucho más grande porque el terreno a regar es mucho más alto que los que hemos citado. Al objeto se han hecho dos socavones a través de cerros de arcilla y de arenas con pedazos de rocas. Llevó estos socavones necesitasen de fortificarlos porque de otra manera el agua minando por los lados haría derrumbar el terreno de arriba y así llena [la] acequia. También se ha construido un pequeño puente sobre el cual pasa la acequia hallándose una pequeña quebrada en el camino. En la excavación de dicha acequia se han encontrados en un terreno arcilloso y en otros terrenos sueltos muchas momias de los antiguos habitantes del lugar; ésta por la mayor parte son bien conservados y todas son puestas en una posición como sentadas con los brazos cruzados sobre el pecho. También muchas son envueltas en paños que algunos son bordados y otros más ordinarios en forma de saco. Todos estos paños son hechos de lana de Vicuña.

40 Atriplex atacamensis. 
PÁG. 35

Con estas momias se hallan enterrados varios cantaritos de tierra y una cantidad de algarrobos que parece haber sido su principal alimento.

Los cerros que rodean Quillagua son los que forman la quebrada y todos no son que grandes depósitos de arcilla y de tierras sueltas con pedazos de rocas. En la mayor parte de estos terrenos se hallan avanzos de vegetación pero es idéntica a la que se halla en el día*.

Paramos en Quillagua el 21 y el 22 para dejar descansar las bestias y para visitar los alrededores y el 20 nos marchamos para Tamentica.

El camino de Quillagua a Tamentica es en general muy bueno por 5 leguas. Se anda sobre un terreno arcilloso duro y muy llano pasando por una pequeña quebradita llamada de la Piedra Cansada. Después se empieza a encontrar los guijarros de yeso tan comunes en el salar y en el camino del sur hasta llegar al Tambillo, pascana situada sobre las faldas de un pequeño cerrito de formación de yeso cubierto de calichales de sal. Los alrededores de este lugar son cubiertos de mucha arena que incomoda mucho la vista, reinando en este lugar

\section{PÁG. 36}

un viento muy fuerte. Del Tambillo a Sipuca el camino también es regular encontrándose solamente de cuando en cuando alguna quebradita. Sipuca es la pascana donde pasamos la noche y es situado en una pequeña quebrada lo que hace conocer por sus cortes de formación de esta parte de la pampa que es compuesta de capas alternadas de tierras sueltas y de guijarros. Esta pascana no tiene agua de modo que no se puede pararse mucho tiempo y a las dos de la mañana del 24 nos pusimos en viaje para llegar a Tamentica la que dista 30 leguas de Quillagua.

De Sipuca nos dirigimos hacia la cercanía a través [de] un terreno cubierto de arena hasta llegar a la Quebrada de Maní.

\footnotetext{
* En todos los terrenos sueltos que hemos citado se encuentran signones (sic) de sílice que a veces son porosos y forman como un tubo siliceoso, y en las pampas se hallan cantos rodados formados por rocas de diferente naturaleza entre las cuales la traquita es la que más abunda.
}

Esta quebrada es bastante honda y tiene un poco de vegetación la que consiste en cardo santo, en algunas chilas en Sorona, pillaya, en otra planta llamada sacasa y también tiene un poco de cultivo lo que consiste en higueras de las cuales hay muchas y dan muy buenos higos y otras plantas que se cultivan solamente en tiempo de avenidas por la escasez del agua como trigo, ají. Para obtener un poquito de agua se ha escavado un socavón porque el agua no es tan profunda, más es en muy poca cantidad. De Maní (que es un pueblo formado solamente por dos o tres casitas abandonadas) subimos una costa

\section{PÁG. 37}

y entramos de nuevo en la pampa. De este punto hasta Tamentica el camino es un continuo sube y baja porque no se hace que pocos pasos se encuentra otra quebrada, todas formadas por las aguas que bajan de la serranía en tiempo de avenidas.

Entre estas quebradas yo citaré solamente la Quebrada Honda la que es muy grande y la quebrada de [espacio] y en fin se llega a la de Tamentica que también es bastante honda.

En esta quebrada se encuentra más vegetación muy variada tanto natural que cultivada. Entre las plantas naturales yo citaré en primer lugar el molle que se halla en mucha abundancia en el pequeño Valle de Tamentica, la chañara que da unos pequeños frutos llamados pucura de los cuales hacen chicha en Atacama, la chilca, la sacasa, la sorona, la cuiza-cuiza (compuesta que se halla cerca de Huamancas), el chintaguay, la pillaya, el eliotropicun curassavicum, el elquina (cestrum), la jara, el algarrobo, el tamarugo, la higuerilla, y muchos otros que son demasiado largo el nombrarlos. Entre las cultivadas tenemos porotos en gran cantidad, ciruelas de Europa, manzanas, membrillos, granadas, higos, algún durazno, maíz, trigo, cebada, alfalfa, además de muchas plantas de hortaliza. En este terreno crece cualquier clase de plantas basta que se abone

\section{PÁG. 38}

el terreno con huano lo que traen de Huanillos o de Punta de Lobos. Apenas entrado en la quebrada viniendo de Maní se encuentra el pueblo de Tamentica compuesto de pocas casas situadas en medio de una vegetación muy lozana que estos industriosos habitantes han podido ob- 
tener a pesar de la poca cantidad de agua que pueden disponer, la que sale del terreno como un puquio y se recibe en un depósito para tenerla permanente; de este punto sales las acequias que sirven al regadío de estos terrenos.

El agua no corre por toda la quebrada, mas sale del terreno de trecho en trecho de modo que varios puntos de esta quebrada tienen vegetación y otros no; parece ser debida a la permeabilidad de los terrenos que forman esta quebrada que si no se halla por debajo una capa de arcilla de dura roca el agua no viene a la superficie mas viene absorbida enteramente por el terreno.

Pasado Tamentica se camina sobre terrenos secos entre los cuales la Pampa de Chelis hasta Tiquina, otro pequeño valle donde hay agua y cultivación y algunas casas. Después de este punto la quebrada va estrechándose y cambiando de terrenos siendo antes formada toda de arena y pequeños guijarros reunidos por un barro arcilloso formando en algunas partes los bordes de la quebrada
PÁG. 39

cortados a pique y de la altura de 24 a 30 varas. Los terrenos que suceden a estos son rocas feldespáticas y piroxénicas la que forman un punto un poco difícil a pasar y llamado Cachanga. Pasado este punto casi siempre se halla agua hasta Huatacondo. Este es un pueblo un poco grande y donde se cultivan un gran número de perales cuyas peras mandan por toda la provincia. El agua también en este lugar sale de puquios y por medio de acequias bien dirigidas riegan este valle que es el principal de toda la quebrada. Un poco más arriba el agua es permanente.

Entre los productos minerales de esta quebrada se notan minerales de oro, de plata, de cobre, de fierro y níquel los que se hallan cerca de la cordillera, y cerca de Huatacondo se halla alumbre y arcilla fina que sirve allí como de jabón para lavar.

El 25 pasamos a Huatacondo para conocer este lugar y el 26 por la mañana salimos de Tamentica por Matilla.

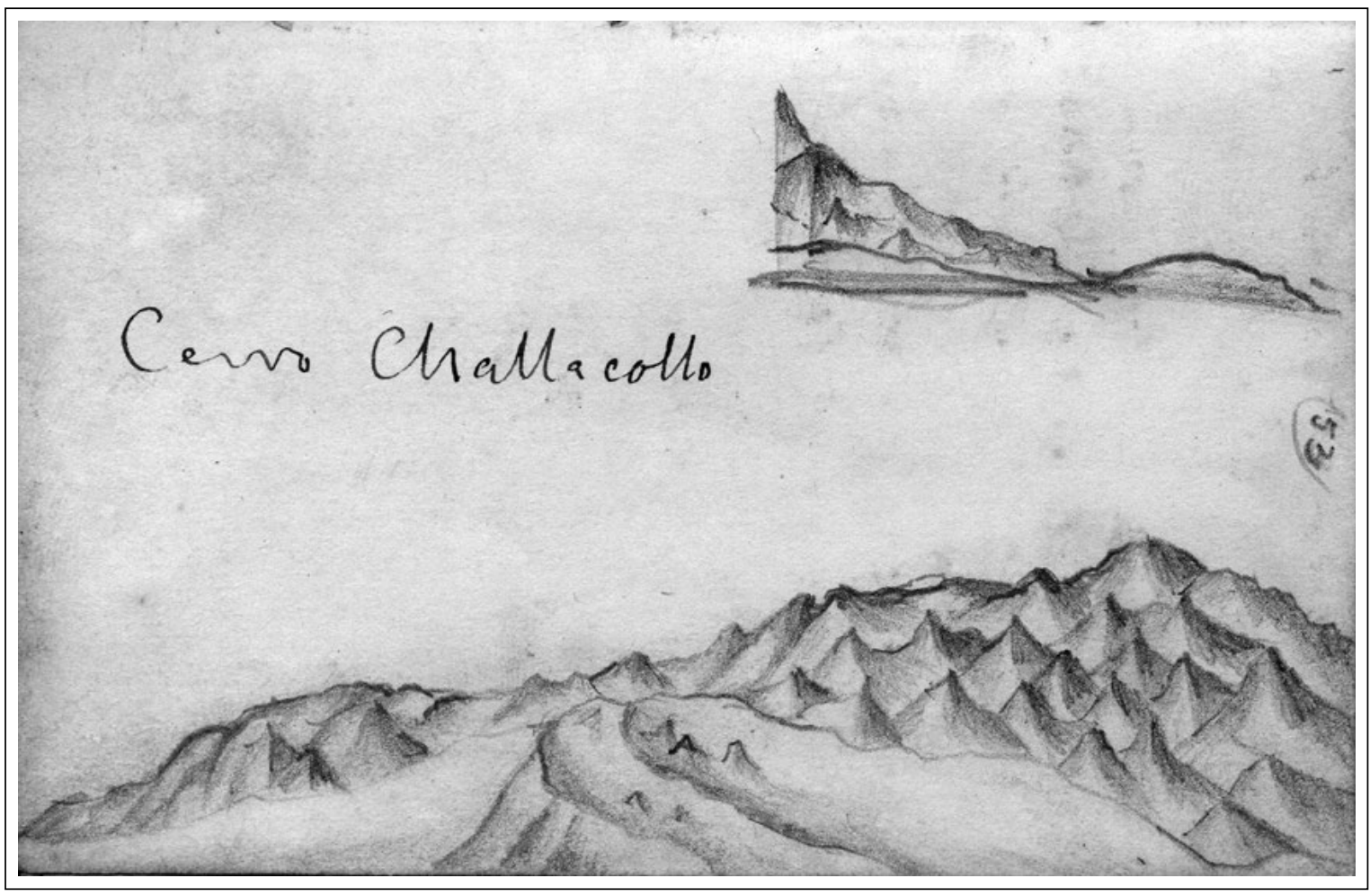

Figura 4. Cerro Challacollo. A. Raimondi, Provincia de Tarapacá, 1853. 
Caminamos por la quebrada para dirigirnos al cerro de Challacollo que dista 5 leguas de Tamentica. (Ver Figura 4). El camino en la quebrada es bueno, mas cuando se sale para acercarse al cerro se entra en un arenal que está esparcido de piedras formadas por la mayor parte de basalto, más se acerca al cerro y

\section{PÁG. 40}

la capa de arena tiene mayor espesor, de modo que cerca del cerro [se] forman médanos muy altos y que cubren en gran parte el cerro. El cerro es de formación muy variada, feldespática en algunos puntos, cuarzosa en otros, piroxénica y también porfírica en otros, y se puede considerar como reunión de muchos pequeños cerros; por la forma parece haber sido muy conocido y su superficie es como sembrada de muchos pequeños conos. Este cerro contiene minerales de plata y cobre y ha sido trabajado en otro tiempo beneficiándose sus metales en Tamentica y en Quillagua, en cuyos pueblos se ven todavía los restos; principalmente en Quillagua es donde existe un trapiche muy bien construido con una rueda horizontal movida por el agua.

Las excavaciones que se han hecho son muchas y todas casi a la sonidad [sic] de la que nombrásemos la principal llamada del Cristo. Esta veta parece haber dado mucha plata por ser abierta con regularidad, los pozos son casi verticales y se baja sobre los desmontes acomodados como una escalera. Después de haber bajado como 12 varas se encuentra algunas excavaciones a derecha más que continúan muy poca y a la izquierda se halla otro pozo de cerca 4 varas de profundidad en el agua que se baja por medio de una escalera de mano y se llega a un punto donde se hallan excavados otros dos pozo en los cuales se baja sobre [una] escalera muy

PÁG. 41

vertical también formada por los desmonte; aquel a la derecha tendrá otras 10 a 12 varas de profundidad, más el [de la] izquierda es muy hondo habiendo echado en él una piedra y habido el ruido de la piedra que bajaba a saltos sobre estos escalones hasta perderse poco a poco el ruido manifestando tener una gran profundidad, no pude bajar en él por falta de luz.

El metal está casi todo en una veta de cuarzo que a veces tiene mucho óxido de fierro. Recogí también algún ejemplar en roca serpentinosa.
Bajamos en cerro de la otra parte y continuamos el camino para Pica el que está en arenal en cercanía del cerro y pues continúa sobre un terreno bastantemente duro hasta llegar en cercanía del Puquio de Obregón donde empieza de nuevo el arenal lo que contiene hasta Matilla.

El Puquio de Obregón situado a 4 leguas de Matilla parece propiamente un oasis en medio del desierto porque situado en medio de un arenal forma una mancha de vegetación que hace muy buena vista. Este puquio esta escavado en socavón en medio de terrenos arcillosos y da el agua casi a superficie con la que se riega esta pequeña isla de vegetación.

Del Puquio de Obregón a Matilla hay 3 leguas de camino, todas en arenal debajo de cual se halla en muchos puntos una capa de yeso.

Matilla es un pueblo regular cuyas casas presentan una buena vista,

\section{PÁg. 42}

siendo todas emblanquecidas con tiza. Este pueblo situado sobre la orilla izquierda de la Quebrada de Chintaguay y fundado sobre una formación traquítica cubierta, pero de un terreno de aluvión de modo que las calles del pueblo y todos los alrededores son cubiertos de arena, lo que fatiga mucho el caminar por estos lugares. Uno de los materiales principales de construcción es la tiza que se halla esparcida sobre el terreno en pequeñas masas como ya hemos notado en varios lugares, allí se muelen estas piedras y por medio de un chimbalete se mezclan. Después con arena y agua se hace una especie de argamasa que después de algún día toma una consistencia y solidez muy grande; es a notar que por 405 días esflorece sobre estas construcciones una especie de sal que se tiene cuidado de barrer hasta que cesa de esflorescencia. Con esta mezcla se hacen también ladrillos bastante sólidos; de modo que con esta tiza y algunas cañas se fabrican las casas.

Las construcciones que demandan mucha solidez además de estos materiales se emplea la traquita compacta que se saca de muy cerca del pueblo; y con estos materiales se ha construido la torre y la iglesia.

La vegetación cerca de Matilla es regular, el ramo principal de cultivo es la viña la que ade 
PÁG. 43

más de cultivarla en panales [sic] se cultiva [espacio] y se puede decir que la mayor parte es cultivada de este modo. Con toda esta cantidad de uva fabrican un buen vino teniendo la costumbre de echar una libra de yeso en cada 2 arrobas de vino para esclarecerlo. Este vino se conserva después en tinajas de tierra. La cantidad de vino que se fabrica anualmente es término medio de 24000 arrobas y el precio corriente de este vino es de $6 \$$ la botija la que contiene dos arrobas. (Ver Figura 5). Además de la viña se cultivan higueras, guayabas, pacaes, perales, granadas, membrillos, algún chirimoyo, alfalfa, algunas palmeras que dan dátiles, sauces y muchas plantas de hortaliza.

La vegetación indígena de estos lugares se va ya asemejando mucho a la de los alrededores de Lima, hallándose además del molle del chañava, de la chilca, tava, sorona y muchas otras comunes con la Quebrada de Tamentica, mucha higuerilla, chamico, mimula hiteses, tricalix, alguna enforbia, cardo santo.

El agua empleada por el riego en las partes bajas en la quebrada o cerca provienen todas de manantiales termales que salen de la roca traquítica que se halla debajo del terreno de aluvión y que en algunas partes viene a salir a la superficie y forma como tantos surtideros llamados ojos de agua; esta agua tiene la temperatura casi constante de $33^{\circ}$ centígrados,

\section{PÁG. 44}

lo que forma baños deliciosos teniendo la misma temperatura del cuerpo.

El punto donde se hallan estos baños se llama Chintaguay y el agua que sale de este punto se recoge en un estanque para distribuirlas después por medio de acequias.

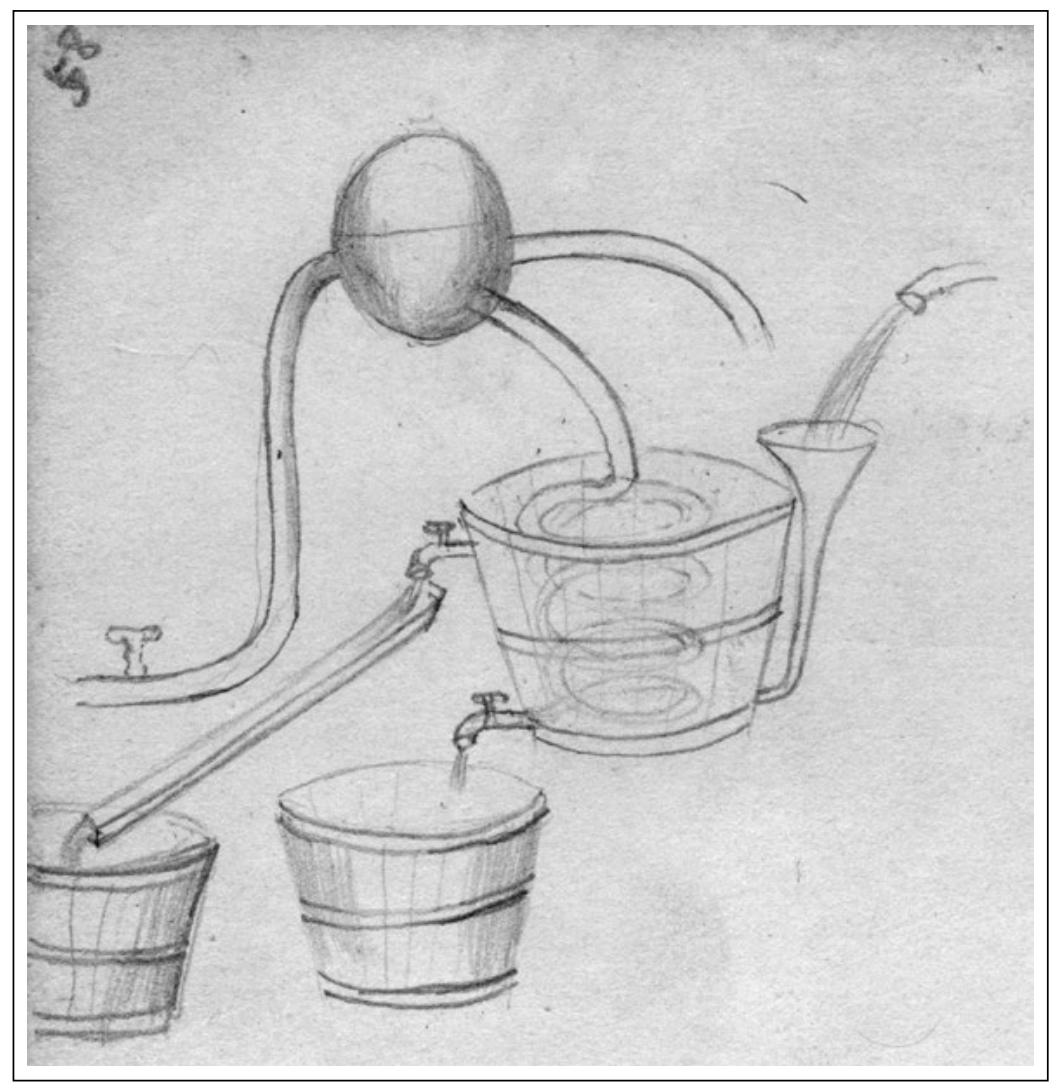

Figura 5. Artefactos para elaborar agua ardiente en el oasis de Pica. A. Raimondi, Provincia de Tarapacá, 1853. 
Sobre estos terrenos traquíticos se halla en la mayor parte un terreno de aluvión compuesto de arcillas y de arenas, en estos terrenos se encuentra una ligera capa de agua la que recoge formando socavones en este terreno. Esta agua es fría y sirve al regadío de los terrenos altos. Apenas afuera de Matilla se halla un cerro llamado Morro, sobre él se encuentra una capa de sal mezclado a fragmentos de rocas traquíticas. En el país usan de esta sal como una purga.

A menos de una legua de distancia más arriba se halla Pica, otro pueblo más grande que Matilla y que tendrá cerca de 1000 habitantes. También en este lugar se hallan ojos de agua termales de los que los principales son los de Concoa y los del Resbaladero. Los de Concoa son situados más arriba y tienen de $33^{\circ}$ a $34^{\circ}$ centígrados siendo la temperatura exterior de $21^{\circ}$. Estas aguas que se ven como a hervir en medio de la cancha de modo que estando en el baño empujan el cuerpo para arriba; se reúnen en una pequeña acequia que acaba en

\section{PÁG. 45}

un estanque que sirve pues para distribuir las aguas. Este puquio está rodeado de muchos árboles tan indígenas que cultivado y vende el lugar muy delicioso para baños.

Un poquito más abajo hacia Pica se halla el resbaladero donde se puede ver en el mismo tiempo salir el agua caliente y la fría. La caliente sale de algunos ojos en medio de la concha y más arriba se han escavado en el terreno de aluvión dos socavones con un poco de agua fría que cae en la misma concha donde sale el agua caliente.

Un poco más abajo de los socavones y a un lado del socavón a [la] derecha se halla una arenaria bastante sólida que a veces está mezclada en pequeñas vetas con una arcilla endurecida.

En algunos puntos, principalmente cerca de Pica y en Pica mismo, el terreno traquítico está a una gran profundidad y entonces la capa de terreno de sedimentos tiene un espesor mucho más grande. En este terreno se han escavado muchos pozos que sirven para abastecer de agua a las casas de Pica y tienen a veces 24 a 30 varas de profundidad según la mayor o menor elevación del lugar.

A pocas cuadras de distancia de Pica he visto un socavón excavado hasta encontrar la traquítica que tiene 31 varas de profundidad vertical y da un agua un poco caliente; parece que debajo de este terreno se hallan algunos ojos de agua ter

\section{PÁG. 46}

mal que se mezcla con el agua fría del terreno de sedimentos y aumenta un poco la temperatura. Este socavón tiene algunas alumbreras por las cuales se puede bajar.

Una legua más arriba de Pica, continuando el camino arriba hacia la quebrada, se llega a un punto donde la quebrada acaba con un barranco a pique del altura de 25 a 30 varas. Este barranco presenta un punto geológico muy importante hallándose terrenos de fusión depositados sobre terrenos de aluvión.

Inferiormente se halla una capa de 8 a 10 varas de espesor formada de arena con cantos rodados hasta [una] altura de dos varas de terreno, hay una pequeña filtración de agua de esta capa que va reuniéndose y formando un rigolo que a poca distancia va partiéndose de nuevo en el terreno siendo muy permeable, más que por medio de una acequia y de algún socavón en el terreno donde sale el agua se podría obtener bastante cantidad de agua para utilizarla. Sobrepuesta a esta capa de guijarros se halla otra de arena un poco menor del espesor de 12 a 15 varas; sobre esta se halla otra de terreno de fusión que es una especie de resinite que tiene el espesor de cerca dos varas, sobrepuestas a todas estas se halla una capa de cerca 3 varas de espesor también de fusión con muchos poros grandes manifestando su origen ígnea y que se acerca más a una traquítica que a cualquier otra roca. Esta tiene esparcida en su masa pequeños riñones de sílice diáfana y muy pura.

Estos terrenos parecen

\section{PÁG. 47}

haber sido levantados en el punto que forma el barranco, porque la capa de resinite que en este punto es altura de cerca [de] 25 varas viene en los lados a bajar (manteniendo siempre el mismo espesor) hasta tocar al fondo de la quebrada.

$\mathrm{Si}$ se hubiese depositado cuando el terreno tenia esta pendencia, siendo esta en el estado casi líquido se habría depositado por su propio peso en una capa de mayor espesor en los lugares más bajos. 
Es muy difícil también explicar la formación de estos terrenos sobrepuestos a terrenos de sedimentos, a primera vista se podría juzgar que estos terrenos de fusión se han hecho pasaje en algún punto otra vez a los terrenos de sedimento y que llegado a la superficie hallánlos en el estado líquido se hayan depositados sobre los terrenos de sedimento de los alrededores; más otra observación hecha sobre el lugar hace pensar que se hayan formado de diferente modo; y es que en medio de la capa de arena se halla una piedra del tamaño de un pie cúbico de la misma resinite que se halla depositada más arriba, lo que hace conocer haberse depositada esta capa de arena después de la formación de la resinite, lo que no se puede explicar de otro modo que la resinite se haya depositada sobre otro terreno [y] que este terreno se haya destruido y depositado un socavón en el cual se haya depositada la arena con el pedazo de resinite que habrá caído.

El 27 y el 28 nos pasamos en Matilla para reconocer los contor

\section{PÁG. 48}

nos y Pica, y el 29 por la mañana nos pusimos en viaje para La Tirana. De Matilla pasamos a La Noria Antigua caminando sobre un arenal. En cercanía de La Noria empezaron los calichales que llevan su nombre; en estos calichales principalmente donde el agua viene casi a la superficie, o sea en las hoyadas se encuentra una sal muy blanca que en Pica y en Tarapacá la emplean como atincar o mezclándola con un poquito de atincar para soldar oro y plata; un poco más adelante hallamos otro calichal que por debajo tenía una sal diferente de las que habíamos visto y que comprimiéndola con una mano se hacía como una masa; más bajo de esta sal se halla una capa de salitre.

En otro calichal levantando el caliche hallamos una sal en polvo cristalina que casi no tiene sabor. Un poco más adelante se halla La Noria la que ahora consiste en una aguada donde se halla agua buena a la profundidad de dos varas, a pocas cuadras se halla otra aguada situada bajo un gran tamarugo que se llama Tamarugo de la Noria. De este punto nos dirigimos a la chacra de Don Mariano Morales Núñez para pasar después a La Tirana. Ente La Noria y la chacra de Núñez se halla bórax en bolas.
La Tirana es un pueblo situado en la Pampa del Tamarugal y construido para beneficiar los

\section{PÁG. 49}

minerales de Huantajaya; al presente los minerales han degenerado mucho y por esta razón han cesado casi todos los trabajos, existiendo en el día un solo buitrón que es de propiedad de Don José Manuel Ribeira, donde todavía se trabaja. El metal entre saja y transporte a La Tirana viene a costar 8 reales el quintal. Se muele por chimbalate los que muelen cada uno 10 arrobas empleando 2 hombres que ganan cada uno un peso y otro hombre que es el cernidor gana 4 reales, de modo que para moler 10 arrobas se gasta 20 reales que con los 10 de transporte y saja hacen 30 reales, o sea 3 reales por cada arroba de metal molido. El beneficio se hace a crudo amalgamándole con mercurio y después reforzado bajo de capirusas. El metal que se sacaba antiguamente era muy bueno, siendo la plata nativa incrustada en un carbonato de cal, al presente no se halla más de este metal y trabajándose metales muy pobres, encontrando raramente metales que tiene 50 o 60 marcos de plata cada cajón.

La Tirana, de los pueblos situados en la pampa, es el mejor, tiene algunas casas un poco decentes y bien construidas, el agua es regular y a la profundidad de cerca de 8 varas, siendo muy cerca de las oficinas de salitre de La Noria y del Salar abastece a estas de agua dulce.

En La Tirana es también donde se hallan algunos lavaderos a motivo del agua buena porque en La Noria y en el Salar no se puede lavar cortándose todo el carbón en causa del agua salada.

En este pueblo hay una iglesia donde viene alguna vez el cura

PÁG. 50

de Pica para oficiar.

Cerca de La Tirana existe un monte de tamarugos bastante grande habiéndose prohibido el corte bajo pena de una multa porque de otro modo no habría al presente existido un solo árbol cortándose para hacer leña y venderla a las oficinas del salitre. 
Paramos en La Tirana el 30 y el 31 para proveernos de cebada de La Noria y para cambiar las bestias las que eran muy maltratadas.

El 1 de Enero 1853 salimos de La Tirana con dirección a Tarapacá. El camino que conduce de La Tirana a Tarapacá tiene 14 leguas de largo y es muy bueno. Casi toda la pampa indica por sus restos haber sido un monte de tamarugos, retamas y pillagas.

A la distancia de cerca 6 leguas de La Tirana empieza a aparecer algún molle, que se hacen más frecuentes en adelante hasta la distancia de cerca 4 leguas de Tarapacá, donde empieza un pedregal que se continúa hasta adentro de la quebrada. Las piedras esparcidas sobre el terreno son casi todas de origen volcánico, exceptuadas algunas que son cantos rodados de formación cristalina y otras de yeso.

Antes de llegar a la Quebrada de Tarapacá se pasan otras que no se continúan en la pampa; éstas son la Quebrada de Juan Morales sin agua y que tiene su origen cerca de minerales de Laguan, Picunticsa, Yabricoya.

La quebrada que sigue es la de Mamiña que tiene aguas cerca de este pueblo, más que llega a la pampa sin agua.

\section{PÁG. 51}

Mamiña tiene aguas termales sulfurosas. Estas aguas que tienen una temperatura muy alta pasando de $70^{\circ}$ en algunos puntos, sirven cuando están enfriadas para el cultivo de la quebrada. Cerca de este pueblo se encuentra un mineral de cobre.

Un poco más adelante, en el camino por Tarapacá, se ve otra quebrada llamada de Quipisca que tiene un pequeño chorrito de agua que no basta para la cultivación y solamente se cultiva en tiempos de avenidas.

En fin, se llega a la Quebrada Tarapacá la que es formada toda por terrenos de aluviones antiguos teniendo por bordes cerros elevados formados enteramente de capas de arenas, guijarros y arcilla.
Entrando en la quebrada no se ve ningún indicio de vegetación sino que un poco más adelante del alto de una pequeña costa se descubre un valle más bajo y el pueblo de Guaraciña. Este pueblo que ahora es casi enteramente deshabitado servía en otro tiempo por el beneficio de los metales de Huantajaya, como muchos otros que ya hemos nombrado; al presente se halla solamente alguna casita habitada cuyos habitantes se dedican al cultivo de un poco de terreno teniendo muy poca agua. Caminando una legua más arriba en la quebrada por un camino sombreado de molles muy hermosos y de chilcas se llega a Tarapacá que es la Capital de la provincia. Esta ciudad tiene sus calles muy tortuosas.

\section{PÁg. 52}

y muy pocas casas construidas con un poco de solidez, tiene 2 iglesias una pegada a la otra y un solo campanario fabricado con piedras de traquite que se sacan de un cerro cerca de panteón. La plaza de la iglesia es regular. Esta ciudad tiene un subprefecto y un gobernador, tiene una escuela pública, un panteón fabricado al otro lado de la quebrada sobre una planicie un poco elevada.

Las plantas comunes a esta quebrada son el molle, la chitea, algún algarrobo, la sorona, el charnico, el elguina, la chañara, y muchas otras plantas comunes con las otras quebradas, además encontré en un alfalfal una especie de celsia. La cultivación es un poco [atrasada], es bien verdadero que tiene poca agua, sin embargo se podría cultivar más de lo que cultivan actualmente. La mayor parte de las chacras no tienen [más] que sonora, y aunque esta yerba [es] bien comida por los animales, es muy inferior a la alfalfa.

El agua que baña esta quebrada y que sirve al riego de los terrenos, tiene su origen de vertientes que salen de trecho en trecho en la quebrada como en la de Tamentica, de modo que parte de la quebrada está cultivada y parte no. Suelen, pero de cuando en cuando, venir desde el interior sus avenidas según que a veces producen más mal que bien porque arrastran grandes cantidades de piedra que arruinan con todo lo cultivado. 


\section{Índice Onomástico}

Castro, Pedro (propietario de pascana): p. 18

Digoy, Bernardo: p. 23

Morales y Núñez, Mariano (propietario de chacra): pp. 22,48

Palape, Lucas (propietario de pascana): p. 21

Quinto (piqueño constructor del pozo de su nombre): p. 24

Ribeira, José Manuel (propietario de buitrón en Huantajaya): p. 49

Santos, Eduardo (propietario de aguada): p. 19

Williamsom, Juan (propietario de oficinas salitreras): p. 25

\section{Índice Toponímico}

Aguada Tamarugo de la Noria: p. 48

Aguada de Reyes: pp. 16, 18

Aguada de Chanavaya: p. 20

Aguada de Eduardo Santos: p. 19

Aguada de Lucas Palape: p. 21

Aguada de Santa Ana: pp. 20, 21

Aguada de San Mauricio: p. 24

Aguada de Hidalgo: p. 21

Aguada de Cabién: p. 24

Aguada de San Francisco: p. 21

Aguada Nueva: p. 26

Aguada Vieja: p. 26

Arica: pp. 3, 4

Atacama: p. 37

Bahía de la Independencia: pp. 1, 2

Bajada del Sur: p. 28

Bolivia: pp. 30,32

Cachanga: p. 40

Calate: pp. 29, 30, 32

Camaná: p. 2

Camino de la Cabrería: pp. 15, 16

Cerro de Santa Rosa: p. 5

Cerro Morro: p. 44

Cerro de Challacollo: p. 39

Challapocito: p. 19

Challapozo: pp. 14, 15, 16, 17, 19, 20, 23, 24

Chayas: p. 23

Chintaguay (vertiente): p. 44

Cobija: p. 30

Concoa (agua termal): p. 44

Cosallón de la Rinconada (corral): p. 13

Europa: p. 37
Guaraciña: p. 51

Huamancas: p. 37

Huanillos: p. 38

Huantajaya: pp. 13, 49, 51

Huatacondo: pp. 29, 39

Iquique: pp. 2, 4, 5, 7, 26, 30

Islay: p. 2

Laguan (mineral): p. 50

La Noria: pp. 4, 5, 10, 12, 13, 15, 21, 22, 25, 48, 49, 50

La Noria Nueva: pp. 5, 20, 22

La Noria Vieja: p. 48

La Tirana: pp. 48, 49, 50

Lima: pp.1, 2, 43

Los Linches (oficinas salitreras): p. 25

Mamiña: pp. 50, 51

Maní (pueblo): pp. 36, 38

Matilla: pp. 39, 41, 42, 44, 47, 48

Monte Grande (bosque): p. 21

Monte de la Soledad (bosque): pp. 27, 29

Morro de Arica: p. 3

Pampa del Tamarugal: p. 12, 48

Pampa de Chelis: p. 38

Pascana de Pedro Castro: pp. 17, 18

Pascana del Tronco: pp. 19, 20

Pascana de Tambillo: pp.35, 36

Patillo (puerto): p. 26

Perú: pp. 3, 30, 32

Pisco: p. 2

Pica: pp. 24, 25, 41, 44, 45, 46, 48, 50

Picunticsa (mineral): p. 50

Pintados: p. 24

Pozo de Quinto: pp. 23, 24, 25

Pozo de Obregón: p. 24

Punta de Lobos: p. 38

Puquio de Obregón: p. 41

Puquios de los Huatacondos: pp. 29, 30

Puquios de Quillagas: p. 29

Quebrada de Quipisca: p. 51

Quebrada de la Cabrería: p. 17

Quebrada de Juan Morales: p. 50

Quebrada de Guanguac: p. 32

Quebrada de Chala: p. 2

Quebrada de Chilca: p. 2

Quebrada de Chanavaya: p. 20

Quebrada de: p. 30

Quebrada de Mani: p.36

Quebrada de Tamentica: pp. 43, 52 
Quebrada de la Piedra Cansada: p. 35

Quebrada de Chintaguay: p. 42

Quebrada Honda: p. 37

Quebrada de Tarapacá: pp. 50, 51

Quillagua: pp. $32,33,35,36,40$

Resbaladero (agua termal): pp. 44, 45

Rinconada: pp. 12, 13, 14, 15, 26

Río Loa: pp. 30, 32, 33

San Gallian: pp. 1, 2

Salar: pp. 25, 49

Santa Rosa: p. 13

Sipuca: p. 36

Sur Vieja (oficina salitrera): pp. 27, 28

Tamentica: pp. 35, 36, 37, 38, 39, 40

Tarapacá (pueblo): pp. 48, 50, 51

Tiquina: p. 38

Yabricoya (mineral): p. 50

Valle de Tamentica: p. 37

Veta del Cristo (de plata): p. 40 
